\title{
Bicameral Conflict Resolution in the European Union: An Empirical Analysis of Conciliation Committee Bargains
}

\author{
THOMAS KÖNIG, BJORN LINDBERG, SANDRA LECHNER AND \\ WINFRIED POHLMEIER*
}

This article is a study of bicameral conflict resolution between the Council and the European Parliament in the European Union, which has established a bicameral conciliation process under the co-decision procedure. Scholars commonly agree that the European Parliament has gained power under the co-decision procedure, but the impact of the conciliation process on the power distribution between the Council and the European Parliament remains unclear. The scholarly debate suggests that the power of the institutional actors depends on their proximity to the status quo, the (im-)patience and the specific preference distribution of the institutional actors, although most analyses assume that the Commission plays an insignificant role. Using an ordered probit model, this study examines the power distribution between the two institutional actors, the factors for their bargaining success and the role of the Commission in the period between 1999 and 2002 . The findings show that the European Parliament wins most conflicts, but that the Council is more successful in multi-dimensional disputes. The results confirm some theoretical claims made in the literature, such as the importance of the status quo location and of preference cohesiveness. However, they also reject a major assumption in the literature on the irrelevance of the Commission in the conciliation process, which we show to have an influential informational position for parliamentary success.

\section{THE CONCILIATION COMMITTEE: INSTITUTION OF BICAMERAL CONFLICT RESOLUTION}

This study examines bicameral conflict resolution in the conciliation process of the European Union (EU). Compared to the insightful scholarly discussion on the merits of bicameralism in general, and the increasing role of the European Parliament (EP) in EU legislation in particular, we have little evidence on the mechanism of the conciliation process and the distribution of power between the European Parliament and the Council in the conciliation committee. The predominant view is that conciliation committees are smaller, and therefore it is easier to bargain and trade votes in a co-operative manner. ${ }^{1}$ This co-operative perspective has drawn attention to the question of bicameral representation in conciliation committees and shifted the focus away from institutional characteristics of decision making and the analysis of conciliation outcomes. In their seminal study on bicameralism, Tsebelis and Money remind us of the mixed nature of conciliation committees: 'decision making in these committees is cooperative', but 'the composition of the committee, its decision-making rule, and the set of bicameral restrictions are critically important to the results of bicameral bargaining'.2

* König: German University of Administrative Science, Speyer; Lindberg, Department of Government, University of Uppsala; Lechner and Pohlmeier, Department of Economics, University of Konstanz.

${ }^{1}$ Saul Levmore, 'Bicameralism: When Are Two Decisions Better than One?' International Review of Law and Economics, 12 (1992), 145-62, p. 150.

${ }^{2}$ George Tsebelis and Jeanette Money, Bicameralism: Political Economy of Institutions and Decisions (Cambridge: Cambridge University Press, 1997), pp. 116, 118. 
In the EU conciliation committee, the bicameral institutional actors are the Council and the European Parliament with equally sized delegations, and both institutional actors have to accept the final joint text under closed rule. This provides the EU conciliation committee with (conditional) agenda-setting power because none of the institutional actors can amend or renegotiate the final joint text. The Council and the European Parliament may only accept or reject the proposal of the conciliation committee, which solves most of the bicameral conflicts between the institutional actors. But how does the conciliation committee produce these texts? Do the European Parliament and the Council symmetrically share the power in this process, or can the Commission direct the outcome of the conciliation committee? And which factors are relevant for influencing the outcome-does internal cohesiveness, (im-)patience or a status quo bias change the power distribution between the institutional actors in the conciliation process?

With the sole exception of Rasmussen, ${ }^{3}$ scholars commonly assume that the Commission, the initiator of EU legislation, no longer plays a substantial role in influencing the conciliation outcome. ${ }^{4}$ Because the Council and the European Parliament can change the proposal without Commission approval, they are perceived to be the only decisive co-legislative institutional actors. However, scholars disagree on the power distribution between the two institutional actors in the conciliation process. Napel and Widgren find a status quo bias of outcomes and a bargaining advantage for the Council due to the higher (qualified) majority threshold. ${ }^{5}$ Tsebelis predicts that 'the Council and the EP must bargain on equal footing over the final legislative outcome, with no prior bargaining advantage inherent to either institution. ${ }^{6}$ If there are infinitely patient co-legislators, or they are equally patient with a random draw determining which actor makes the first move, Tsebelis and Garrett expect the Nash 'split-the-difference' outcome. ${ }^{7}$ Others make assumptions on the departure of the process and draw their conclusion from the first-mover bargaining advantage for one of the two institutional actors. Garrett and Crombez suppose that the Council takes the lead in this process by submitting a proposal to the European Parliament. ${ }^{8}$ Steunenberg and Dimitrova assume that the member state holding the Council presidency makes a first offer to the European Parliament. ${ }^{9}$ Other studies propose the opposite,

3 Anne Rasmussen, 'The Role of the European Commission in Co-decision - A Strategic Facilitator Operating in a Situation of Structural Disadvantage', European Integration Online Papers, 7 (2003), http://eiop.or.at/eiop/ texte/2003-010a.htm.

4 Although the Commission has the sole right to initiate legislation, it has no gatekeeping power (Heiner Schulz and Thomas König, 'Institutional Reform and Decision-Making Efficiency in the European Union', American Journal of Political Science, 44 (2000), 653-66).

5 Stefan Napel and Mika Widgren, 'EU Conciliation Committee: Council 56 versus Parliament 6', CEPR Discussion Paper, No. 4071 (2003); Stefan Napel and Mika Widgren, 'Bargaining and Distribution of Power in the EU's Conciliation Committee', CESifo Discussion Paper, No. 1029 (Munich: University of Munich Centre for Economic Studies, 2003).

${ }^{6}$ George Tsebelis, Veto Players: How Political Institutions Work (New York: Russell Sage Foundation, 2002), p. 265.

${ }^{7}$ George Tsebelis and Geoffrey Garrett, 'Legislative Politics in the European Union', European Union Politics, 1 (2000), 9-36, p. 25; Geoffrey Garrett, 'The Politics of Legal Integration in the European Union', International Organization, 49 (1995), 171-81.

${ }^{8}$ Christophe Crombez, 'The Co-decision Procedure in the European Union', Legislative Studies Quarterly, 22 (1997), 97-119; Christophe Crombez, 'The Treaty of Amsterdam and the Codecision Procedure', in Mark Aspinwall and Gerald Schneider, eds, The Rules of Integration (Manchester: University of Manchester Press, 2000), pp. 101-22.

9 Bernard Steunenberg and Antoaneta Dimitrova, 'Interest, Legitimacy, and Constitutional Choice: The Extension of the Codecision Procedure in Amsterdam' (unpublished, University of Twente, 1999). 
allowing the European Parliament to make an offer by amendment, ${ }^{10}$ and Crombez provides the Council and the European Parliament with agenda-setting rights in the conciliation process. ${ }^{11}$

Neither the EU conciliation process nor these partly opposing views on the power distribution of the institutional actors have been evaluated in an empirical analysis, and the different factors claimed to endow the institutional actors with power have never been tested against one another. ${ }^{12}$ Instead, most authors attempt to explain conciliation power and outcomes through one theoretical lens, which provides one of the institutional actors with a first-mover advantage, excludes the role of the Commission, assumes the location of an institutional actor closer to the status quo, attributes (im-)patience or supposes unitary institutional actors with a specific preference distribution (in most cases with a symmetric Euclidean preference function). In this study, we take a different approach and try to examine the explanatory power of these factors according to a quantitative analysis of the EU conciliation committee bargains with location of the Council's and the EP's collective bargaining position. Our data cover the period from 1 May 1999 to 31 July 2002 and include an almost complete set of seventy-three conflicts that were negotiated and solved in the conciliation committee after the Treaty of Amsterdam reforms had entered into force. ${ }^{13}$

For the purpose of analysis, we gathered data by interviewing experts of all cases in the conciliation process. In keeping with Hammond and Miller's bicameral model and the work of Tsebelis and Money, ${ }^{14}$ we asked the parliamentary rapporteurs to identify the conflict line between the institutional actors, the location of the collective bargaining position of the Council, European Parliament, Commission and status quo, the cohesiveness of their collective position and the impatience of the institutional actors. We evaluated these estimates using other data sources, such as the Activity Reports from the Conciliation Secretariat of the European Parliament and the Legislative Observatory of the European Parliament. These sources helped us to validate the set of selected issues and the point locations of the institutional actors' positions in budgetary affairs. Moreover, a cross-check of the point estimates of the actors' positions, location of the status quo and outcome reveals an extremely high match between our estimated positions and the Decision-making in the European Union (DEU) data, even though DEU experts were mainly affiliated with Council institutions. ${ }^{15}$ In addition to these expert data, we added some institutional characteristics of the conciliation process, such as the Council presidency and the party group membership of the rapporteur, and we controlled for the

${ }^{10}$ Bernhard Steunenberg, 'Codecision and Its Reform: A Comparative Analysis of Decision-making Rules in the European Union', in Bernard Steunenberg and Frans van Vught, eds, Political Institutions and Public Policy: Perspectives on the European Decision-Making (Dordrecht: Kluwer Academic Publishers, 1997), pp. $205-29$.

11 Crombez,: 'The Treaty of Amsterdam and the Codecision Procedure', pp. 101-22.

12 There are some empirical studies on how many parliamentary amendments survive conciliation, whether these amendments are important, and what the chances are of the European Parliament enjoying such success (Amie Kreppel, The European Parliament and Supranational Party System: A Study in Institutional Development (Cambridge: Cambridge University Press, 2002)).

13 The Amsterdam Treaty established a modified version of the co-decision procedure, in which conciliation is possible. Other procedures of EU decision making, such as the consultation and the co-operation procedure, do not provide for a conciliation process.

14 Tom Hammond and Gary Miller, 'Core of the Constitution', American Political Science Review, 81 (1987), 1155-74; Tsebelis and Money, Bicameralism.

15 Robert Thomson, Frans N. Stokman, Christopher H. Achen and Thomas König, eds, The European Union Decides (Cambridge: Cambridge University Press, 2006). 
environment of the committee bargains, in particular for the dimensionality of the proposal and the time span between the proposals.

The findings show that the European Parliament wins most conflicts, but that the Council is more successful in multi-dimensional disputes; only 18 per cent of the seventy-three conflicts resulted in a tie. Using an ordered probit model, the EP wins against the Council if the latter is more distant from the status quo. Cohesiveness of preferences is relevant for the European Parliament and Council, but only member states can profit from parliamentary non-cohesiveness. Contrary to current literature, we provide evidence that the Commission has a significant impact on conciliation outcomes and bargaining success. The European Parliament wins even if the Council is supported a little by the Commission. However, the Council's probability of winning is continuously increased by Commission support. In the following sections, we first introduce the basic features of the conciliation process and the conciliation committee of the European Union. Next, we briefly review the literature on bicameralism and conciliation committees in order to derive our hypotheses on conciliation bargains and outcomes. Finally, we present our data and findings.

\section{THE EU CONCILIATION PROCESS: PROCEDURES AND CONFLICTS}

With the entry into force of the Maastricht Treaty on 1 November 1993, the first version of the co-decision procedure (Art. 189b) introduced the EU conciliation process and its committee. A modified version was established by the Treaty of Amsterdam on 1 May 1999, which officially intended to accelerate legislative decision making under the co-decision procedure (Art. 251). ${ }^{16}$ Upon closer inspection of the conciliation process, the Maastricht procedure differs from the Amsterdam version in three important respects:

-Under the Amsterdam version, the Council can adopt the proposed act at the first reading if it agrees with the parliamentary amendments.

- The European Parliament can adopt the legislative act at the second reading if it does not want to amend the common position. Neither of these two options was possible under the Maastricht version of the codecision procedure.

-If the conciliation committee failed to produce a joint text under the Maastricht version, the Council could just reaffirm its prior position in a third reading, possibly with some of the amendments previously proposed by the European Parliament. This was no longer possible under the Treaty of Amsterdam (for more detail, see Figure 1). ${ }^{17}$

16 The co-decision procedure starts with a Commission proposal, which is sent to both institutional actors, the European Parliament and the Council. The Council, acting by qualified majority after obtaining the opinion of the European Parliament, may adopt the proposal if it approves all the proposed parliamentary amendments, or, if the European Parliament did not propose amendments; otherwise the Council adopts a common position and sends it to the European Parliament, and the Commission also informs the European Parliament of its position. Within three months, the European Parliament can either approve the common position of the Council, reject it or propose amendments to the common position. If the Council does not accept the parliamentary amendments within three months, a conciliation committee must be convened. The conciliation committee successfully produces a joint text, the European Parliament and the Council have to adopt it within six weeks.

17 Amendments not voted on by the European Parliament in the second reading cannot be discussed during the negotiations (Michael Shackleton, 'The Politics of Codecision', Journal of Common Market Studies, 38 (2000), 325-42, p. 335), see also Julie Garman and Louise Hilditch, 'Behind the Scenes: An Examination of the Importance of the Informal Processes at Work in Conciliation', Journal of European Public Policy, 5 (1998), 271-84, p. 282. 


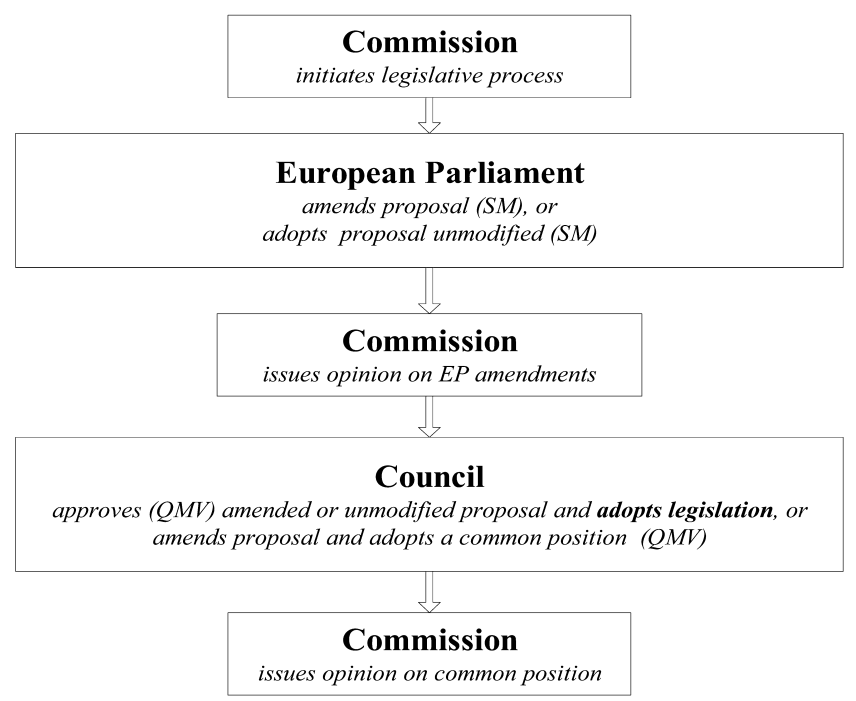

\section{Second Reading (3 months both for Council and European Parliament)}

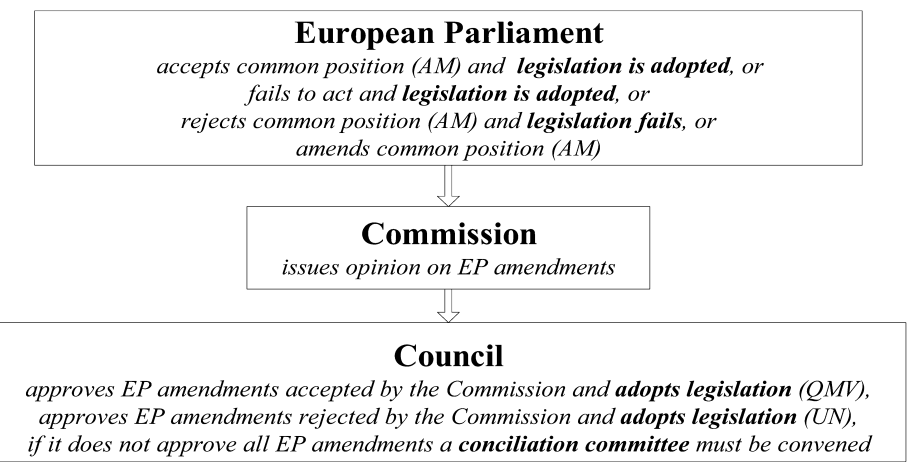

\section{Conciliation (6 weeks, 25 Council and EP members, 1 Commission representative)}

EP delegation (SM) and Council delegation (QMV) adopt Joint Text, otherwise legislation fails

\section{Third Reading (6 weeks)}

\section{European Parliament}

adopts Joint Text (SM) and legislation is adopted, or fails to act and legislation fails, or

rejects common position (SM) and legislation fails

\section{Council}

adopts Joint Text (QMV) and legislation is adopted, or fails to act and legislation fails, or

rejects common position (QMV) and legislation fails

Fig. 1. The co-decision procedure: Maastricht and Amsterdam version

Note: $\mathrm{SM}=$ simple majority, $\mathrm{AM}=$ absolute majority, QMV = qualified majority voting, $\mathrm{UN}=$ unanimity.

Source: Richard Corbett, Francis Jacobs and Michael Shackleton, The European Parliament, 4th edn (London: John Harper, 2000); Simon Hix, The Political System of the European Union, 2nd edn (London: Palgrave, 2005). 
With the entry into force of the Treaty of Amsterdam, the conciliation committee became the last stage of the legislative game before both the Council and the European Parliament take the final vote on the joint text under the closed rule. Abolishing the third reading, where the Council could reaffirm its prior position, suggests that the current conciliation committee is provided with important (conditional) agenda setting power - if the institutional actors still disagree after the first reading. ${ }^{18}$ According to Table 1, 25 per cent of legislation decided under co-decision is settled in the first reading; most of the cases are decided in the second reading, and about 24 per cent are negotiated in the conciliation process.

TABLE $1 \quad$ Cases under Co-decision (May 1999 to July 2003)

\begin{tabular}{lcccc}
\hline \hline & Co-decision & First reading & Second reading & Conciliation \\
\hline Number of cases & 291 & 74 & 148 & 69 \\
Percentage & $100 \%$ & $25 \%$ & $51 \%$ & $24 \%$ \\
\hline \hline
\end{tabular}

Due to the expanded scope of the co-decision procedure allowed by the Treaty of Amsterdam, the number of co-decision cases has increased significantly. ${ }^{19}$ Today, the procedure applies to thirty-eight policy areas, making the Council and the European Parliament frequent co-legislative partners. ${ }^{20}$ Before the accession of ten new members from Eastern and Southern Europe on 1 May 2004, the conciliation committee was composed of fifteen members from the Council (one from each country) and an equal number of EP members, of which three are permanently elected for a one-year period. ${ }^{21}$

After the parliamentary stage, the Council has three months to approve all EP amendments by qualified majority (those amendments that have been negatively commented on by the Commission need unanimous agreement), or, in agreement with the president of the European Parliament, a conciliation committee can be convened. This

\footnotetext{
${ }^{18}$ Regarding the success of conciliation committees, legislative studies have stressed the agenda-setting power under closed rule (David Baron and John Ferejohn, 'Bargaining in Legislatures', American Political Science Review, 89 (1989), 1181-206). Using the spatial model of legislative choice, Ken Shepsle and Barry R. Weingast ('The Institutional Foundations of Committee Power', American Political Science Review, 81 (1987), 85-104) show that the conciliation committee is the 'institutional foundation of committee power'. Due to the closed voting rule, such committees have an ex-post veto, which enables the standing committee to re-enforce its position, after the proposal has been considered by both the Senate and House floors (Shepsle and Weingast, 'The Institutional Foundations of Committee Power', p. 95). Informational approaches argue that committees are faithful agents of their parent chambers because they determine the voting rules for the conference report (Thomas Gilligan and Keith Krehbiel, 'The Organization of Informative Committees by a Rational Legislature', American Journal of Political Science, 34 (1990), 531-64; Keith Krehbiel, Information and Legislative Organizations (Ann Arbor: University of Michigan Press, 1991)). The right to amend a bill in conference and to present the conference report to the parent chambers under closed rule is the highest incentive for conferees to specialize (Krehbiel, Information and Legislative Organizations, p. 199).

${ }_{19}$ Simon Hix, The Political System of the European Union, 2nd edn (London: Palgrave Macmillan, 2005).

${ }^{20}$ Michael Shackleton and Tapio Raunio, 'Codecision since Amsterdam: A Laboratory for Institutional Innovation and Change', Journal of European Public Policy, 10 (2003), 171-87, p. 172.

${ }^{21}$ EP representation is a mixture between the issue-related flexible model of the US Congress and the German model of a permanent conciliation committee: three members from the EP vice-presidents, the chair and the rapporteur of the standing committee having jurisdiction over the proposal, and ten additional members selected by the political parties (Tsebelis and Money, Bicameralism: Political Economy of Institutions and Decisions, p. 204).
} 
starts the conciliation process, in which the conciliation committee may approve a joint text within six to eight weeks that must ultimately be approved by the European Parliament and the Council under the closed rule. The parliamentary delegation is formally led by one of the three permanent vice-presidents of the European Parliament, the Council delegation is always chaired by the Council presidency. ${ }^{22}$ During the six to eight weeks in which the conciliation committee has to find a solution, one or two members of the Commission also participate in the meetings without having the right to vote.

A typical example for the current EU conciliation process is the Ozone Directive, which was introduced by the Commission in July 1999. Based on the guidelines of the World Health Organization (WHO), the Commission proposed the introduction of an EU standard for a maximum ozone value $\left(120 \mu \mathrm{g} / \mathrm{m}^{3}\right)$ in order to reduce harmful ozone effects on human health and the environment. In its first reading on 15 March 2000, the European Parliament supported the key objectives of the Commission directive and submitted seventeen amendments. One important amendment was a compliance deadline set for 2010, although the Commission had suggested a more moderate interim solution. Other amendments sought to add requirements for monitoring ozone concentration in the member states. The Commission was to review member state compliance with the directive's measures and report the findings to the public in 2020. Almost one year later, the Council published its common position on 8 March 2001. The common position included ten parliamentary amendments, but the Council rejected a benchmark and the requested public report on the findings. Furthermore, the Council proposed to change some parts of the original Commission text. For example, the common position extended the maximum number of days on which ozone levels could exceed WHO recommendations from twenty to twenty-five days per annum, and it raised the ozone thresholds.

In June 2001, the European Parliament reconfirmed most of the amendments, which were disregarded by the Council. In particular, the European Parliament re-emphasized the Commission's original proposal of twenty days in which the ozone thresholds could be exceeded. The European Parliament also re-emphasized the deadline for achieving the long-term objective of reducing ozone concentrations. On 8 October 2001, the Council reacted and wrote that the member states were unable to approve all parliamentary amendments. The president of the Council, in agreement with the EP president, then convened a meeting of the conciliation committee on 22 November 2001. In the joint text of the conciliation committee, the Council's position on the number of days in which the ground-level ozone could exceed the target value was adopted. However, the European Parliament was successful in keeping the target value at $120 \mu \mathrm{g} / \mathrm{m}^{3}$, and the text obliging member states to achieve this target value by 2010 . The European Parliament successfully insisted on the benchmark date in 2020 for a Commission compliance review and the public report on the findings, too. The rapporteur summarized the situation before the final vote on the joint text thus: 'The Delegation regards the end result of conciliation as satisfactory for Parliament, indeed rather better than might have been hoped for at first reading. It therefore recommends that the House adopt the text. ${ }^{23}$ The final vote on the joint text was on 18 January 2002, and the provisions entered into force on 9 March 2002. Even though

\footnotetext{
${ }^{22}$ Desmond Dinan, Ever Closer Union - An Introduction to European Integration, 2nd edn (Houndsmill, Hants: Macmillan, 1999), p. 285.

${ }^{23}$ Chris Davies, 'Report on the joint text approved by the Conciliation Committee for a European Parliament and Council directive relating to ozone in ambient air' (A5-0454/2001 - 1999/0068(COD)). (2001), http://www.europarl.eu.int/oeil/file.jsp?id = 157782 (26.10.2005).
} 
both institutional actors had to make concessions on a number of issues, the overall impression is that the European Parliament was the more successful actor in the bargaining over the Ozone Directive.

The example of the Ozone Directive demonstrates that the Council cannot overrule the European Parliament in the modified conciliation process. The Council seemed to dominate the agenda, while the European Parliament has successfully amended the proposal. Other case studies confirm this mixed picture. For example, Benedetto and Rasmussen report a 'split-the-difference' scenario, while the case study of Judge and Earnshaw, on the Take Over Directive reveals a more powerful European Parliament. ${ }^{24}$ Their results illustrate how difficult it is to find case evidence for the crucial factors of bargaining success and failure in this process. Before presenting our data on all conciliation cases and outcomes from May 1999 to July 2002, we introduce our research design and derive some hypotheses on the effects of these factors.

\section{DESIGN AND HYPOTHESES FOR BICAMERAL CONFLICT RESOLUTION}

In their seminal study on the mechanism of conciliation committees in the European Union, France, Germany, Japan, Switzerland and the United States, Tsebelis and Money use the Rubinstein model to explain conciliation committee bargains that might have bicameral restrictions, in particular from the parent committees. ${ }^{25}$ Under the assumption of co-operative decision making and Euclidean preferences, their explanation refers to the model of Hammond and Miller, showing that the line connecting the centres (of the yolks) of the two institutional actors is the privileged dimension of conflict and compromise in bicameral legislatures. ${ }^{26}$ Whether it is the core (which rarely exists in multidimensional spaces) or the uncovered set or the tournament equilibrium (which always exists), bicameralism produces this privileged line because all other lines would increase the conflict and bargaining distances between the institutional actors, and thus decrease their benefits. ${ }^{27}$ In other words, bicameralism can reduce conflicts involving a multitude of dimensions to a one-dimensional conflict and bargaining line between two chambers, who aggregate their cameral preferences by majority rule. ${ }^{28}$

Based on this approach, we shall derive some hypotheses about the bargaining power and outcome, the impact of rules and a few environmental factors, which are

${ }^{24}$ Giacomo Benedetto, 'Rapporteurs as Legislative Entrepreneurs: The Dynamics of the Codecision Procedure in Europe's Parliament' (London: LSE Working Paper, 2004); Rasmussen, 'The Role of the European Commission in Co-decision'; David Judge and David Earnshaw, The European Parliament (Basingstoke, Hants: Palgrave Macmillan, 2003).

25 Tsebelis and Money, Bicameralism. Most often, two models are used in the literature, the Rubinstein model and the Nash bargaining solution. While the co-operative Nash solution does not attempt to explain why the actors reach the bargain (only predicting the bargaining outcome), the non-cooperative Rubinstein model assumes that actors alternate bargaining offers sequentially: one actor makes an offer that the other can accept or reject. If rejected, the second actor makes a counteroffer etc.

${ }^{26}$ Hammond and Miller, 'Core of the Constitution'; Tsebelis and Money, Bicameralism, p. 90.

27 Gary W. Cox, 'Electoral Equilibrium under Alternative Voting Institutions', American Journal of Political Science, 31 (1987), 82-108; William Bottom, Cheryl Eavey, Gary Miller and Jennifer Victor, 'The Institutional Effect of Majority Rule Instability: Bicameralism in Spatial Policy Decisions', American Journal of Political Science, 44 (2000), 523-40.

28 Thomas Bräuninger, 'When Simple Voting Doesn't Work: Mulitcameral Systems for the Representation and Aggregation of Interests in International Organisations', British Journal of Political Science, 33 (2003), 681-703, p. 684. 
also discussed in the literature. Tsebelis and Garrett suggest that the location of the status quo gives a bargaining advantage to the institutional actor located closest to it: 'In our single dimensional model, if the status quo is not located between the EP and the Council, one of the two institutions will be located closer to the status quo than the other. This institution may be able to effectively present the other institution with a take-it-or-leave-it offer'. ${ }^{29}$ Napel and Widgren confirm this view and show that compromises reached by the European Parliament and Council will typically not be close or even exactly in the middle of both institutional actors. ${ }^{30}$ Using a Nash bargaining model, there is a very 'robust bias of the bargaining outcome in favour of the player with the smaller distance between its ideal point and the status quo, i.e. a status quo bias'. ${ }^{31} \mathrm{~A}$ symmetric Nash solution, in the case of a mutually beneficial solution, predicts an agreement closer to the actor with a smaller distance to the status quo. ${ }^{32}$ In other words, the institutional actor that is closer to the status quo is presumed to have an advantage and will therefore be more successful in the conciliation negotiations in terms of being located closer to the outcome:

HYPOTHESIS I: The institutional actor located closer to the status quo will be more successful in the conciliation bargains.

A second hypothesis can be derived from the institutional actors' distribution of the preferences. We define the collective preference of an institutional actor as the sum of individual preferences of the cameral members, which are aggregated within each chamber before inter-cameral bargaining begins. ${ }^{33}$ The outcome of this aggregation is affected by the distribution of the individual preferences and the decision rule applied in each chamber, because it can shift the location of the respective pivotal member in one or the other direction. Majority rule together with a great number of parliamentary representatives promotes the random ideal point of the pivotal member, and hence the collective preference of the European Parliament in the conciliation committee, being distributed around the mid-point of the policy space, while the Council's qualified majority voting (QMV) threshold may result in a distribution that is spread out and close to the status quo. ${ }^{34}$ Due to a high rate of absenteeism among parliamentary members in the plenary session, however, most empirical studies abstain from distinguishing between Council qualified and European Parliament majority voting. ${ }^{35}$ Instead, they suggest that non-unitary actors are more successful in a bargaining situation when their collective preferences are distributed cohesively. ${ }^{36}$ The argument is that the winset of less cohesive non-unitary institutional actors is larger. Because more cohesive non-unitary institutional actors accept

${ }^{29}$ Tsebelis and Garrett, 'Legislative Politics in the European Union', p. 25.

${ }^{30}$ Napel and Widgren, 'EU Conciliation Committee'.

${ }^{31}$ Napel and Widgren, 'Bargaining and Distribution of Power in the EU's Conciliation Committee', p. 2.

${ }^{32}$ Napel and Widgren, 'Bargaining and Distribution of Power in the EU's Conciliation Committee', p. 16.

${ }_{33}$ Tsebelis, Veto Players, p. 154.

${ }^{34}$ Napel and Widgren ('EU Conciliation Committee') assume that the two institutional actors have symmetric preferences and conclude from the difference in the formal voting threshold that the Council is the more powerful actor (Napel and Widgren, 'EU Conciliation Committee').

35 Tsebelis and Money, Bicameralism, p. 205; Amie Kreppel, 'Rules, Ideology and Coalition Formation in the European Parliament: Past, Present and Future', EPRG Working Paper, 4 (1999), p. 1; Tsebelis and Garrett, 'Legislative Politics in the European Union', p. 12.

${ }^{36}$ Tsebelis, Veto Players, p. 53. 
fewer alternatives that beat the status quo, the bargaining outcome is expected to shift towards them. ${ }^{37}$

HYPOTHESIS II: The institutional actor with a more cohesive preference distribution will be more successful in the conciliation bargains.

A third hypothesis suggests that actors attempt to reach agreement by making offers and counteroffers, which might impose costs on both actors. According to Nash, any point in the policy space can be mapped into a particular utility pair that reflects actors' preferences and sufficiently describes a bilateral bargaining situation by maximizing the product of both actors' utility gains relative to the status quo. ${ }^{38}$ Because bargaining itself might be time-consuming and resource-consuming, bargaining models specify the actors' risk and time preference. In the Rubinstein bargaining model, the game is driven by impatience which is expressed as a discount factor on an actor's preferences over time with a constant discount rate. ${ }^{39}$ At the actor level, the length of the deliberation process is a function of an actor's patience. Such impatience may be generated by a number of factors, by public opinion pressure or the preference for earlier implementation, and it may differ between the actors. Assuming that actors differently prefer reaching an agreement sooner than later, they may differently discount the final bargain for each additional round of bargaining. The higher the discount rate, the more utility loss an actor faces from each additional round, and the more likely this actor will accept an earlier offer from his counterpart.

HYPOTHESIS III: The institutional actor who is more patient will be more successful in the conciliation negotiations.

In addition to the (time) preferences of the institutional actors, a number of other (institutional) factors may influence the outcome of the conciliation committee. Some authors argue that the Council presidency plays a crucial role in the conciliation process. ${ }^{40}$ 'The presidency is the one clear and only occasional opportunity for a member government to imprint a particular style on the Council, to impose a particular topic on colleagues, or to ride an individual minister's particular hobbyhorse. ${ }^{41}$ This begs the question whether country-specific presidencies pursue a particular style in making more progressive/ conservative bargaining offers to the European Parliament. For example, Mattila and Lane found that Spain and Sweden had the voting behaviour that was most divergent from that of other member states. ${ }^{42}$ Belgium, Finland, France and Portugal displayed similar and

37 We do not enter the debate on the effect of cohesiveness for the yolk as the centre of collective actors without an equilibrium solution. With respect to the size of the winset, we only examine whether - in the case of no equilibrium solution - the less cohesive actor has more room to manœuvre.

38 John F. Nash, 'The Bargaining Problem', Econometrica, 18 (1950), 155-62; John F. Nash, 'Two-Person Cooperative Games', Econometrica, 21 (1953), 128-40.

${ }^{39}$ According to Osborne and Rubinstein ('A Course in Game Theory', p. 36), a present-oriented actor who discounts the future heavily, has a low discount factor and a high discount rate.

${ }^{40}$ Colm O'Nuallain, ed., The Presidency of the European Council of Ministers: Impacts and Implications for National Governments (London: Croom Helm, 1985); Martin Westlake, The Council of the European Union (London: Catermill, 1995); Fiona Hayes-Renshaw and Helen Wallace, The Council of Ministers (London: Palgrave Macmillan,1997); Neil Nugent, The Government and Politics of the European Community (London: Macmillan, 1999); Hix, The Political System of the European Union; Steunenberg and Dimitrova, Interest, Legitimacy, and Constitutional Choice.

41 Hayes-Renshaw and Wallace, The Council of Ministers, p. 144.

${ }^{4}$ Mikko Mattila and Jan-Erik Lane, 'Why Unanimity in the Council?' European Union Politics, 2 (2001), 31-52. 
more moderate voting patterns in the Council. With respect to their findings we will assess whether outlying member states are more successful during their presidencies in the conciliation bargains. ${ }^{43}$ Accordingly, one might expect that conciliation agents with extreme positions are advantageous for the (median) institutional actor.

HYPOTHESIS IV: When the Council presidency is held by a country with an outlier Council voting pattern, the Council will be more successful in the conciliation negotiations.

Like the Council presidency, the role of the parliamentary rapporteur may also affect the conciliation outcomes: 'It is the job of the rapporteurs to prepare initial discussion on the subject within the committee, to present a draft text, and to amend it, if necessary, to take account of the committee's observations or of new developments. ${ }^{44} \mathrm{He}$ is responsible for the legislative proposal throughout all of the readings in the decision-making process. Because the parliamentary rapporteur plays such a crucial role in the formulation of the parliamentary position, we also control for the party membership of the rapporteur. In the past, the two major party groups in the European Parliament, the Party of European Socialists (PES) and the European People's Party - European Democrats (EPP-ED), always had more than 50 per cent of the seats in the European Parliament. Together with the Liberals, these two party groups also have the highest cohesion records in the European Parliament. ${ }^{45}$ Comparable with the Council, this would suggest that sending agents with extreme positions is advantageous for the (median) institutional actor:

HYPOTHESIS V: If the rapporteur of the parliamentary delegation to the conciliation committee is a member of neither the EPP-ED nor the PES group, the European Parliament will be more successful in the conciliation negotiations.

The Commission does not have the right to vote in the conciliation committee, but it is 'its duty is to attempt to reconcile the positions of the Council and the Parliament' (Art. 251.4 TEC). ${ }^{46}$ The parliamentarian conciliation secretariat states that the 'Commission can be invited to propose compromise texts' to the Council and the European Parliament in the conciliation committee. ${ }^{47}$ Most scholars thus conclude that the Commission lost its power in the co-decision procedure and does not play an important role under the conciliation committee. ${ }^{48}$ Rasmussen corroborates the view of the Commission as a mediator in conciliation with her empirical evaluation of the Commission's role under co-decision. ${ }^{49}$ Accordingly, the Commission might have an important informal role in

43 During our period of study from March 1999 to July 2002, the following countries held the Council presidencies: Finland, Portugal, France, Sweden, Belgium and Spain. According to Mattila and Lane ('Why Unanimity in the Council?'), these presidencies exhibited a specific voting pattern in the Council.

44 Richard Corbett, Francis Jacobs and Michael Shackleton, The European Parliament, 4th edn (London: John Harper, 2000), p. 117.

45 Simon Hix, Abdul Noury and Gérard Roland, 'Understanding the European Parliament: Party Cohesion and Competition, 1979-2001' (unpublished research paper, 2002), p. 28.

46 Damian Chalmers, European Union Law Volume I - Law and Government (Dartmouth: Ashgate, 1999), p. 173.

47 Parliamentary Conciliation Secretariat, Activity Report 2000-2001 (2001) at: http://www.europarl.eu.int/ code/information/activity_reports/activity_report_2001_en.pdf (23.03.2002), p. 14.

48 Steunenberg, 'Codecision and Its Reform'; Crombez, 'The Treaty of Amsterdam and the Codecision Procedure'; Tsebelis and Garrett, 'Legislative Politics in the European Union'.

49 Rasmussen, 'The Role of the European Commission in Co-decision', p. 4. 
the conciliation process. Pollack distinguishes between four situations in which the Commission is able to perform an informal agenda setting role, when information asymmetries exist to its advantage, distributional consequences are low, the cost of waiting is high and it is supported by networks of non-legislative actors. ${ }^{50} \mathrm{We}$ accordingly expect:

HYPOTHESIS VI: The institutional actor with more similar preferences to the Commission will be more successful in the conciliation negotiations.

In addition to these preference, institutional and coalition variables, we also control for the number of dimensions of a proposal and the time span between the proposals. While the dimensionality may indicate the degree of a conflict, the time trend controls for the independency of our cases over time. If the independence assumption on the error term distribution is violated, the ordered probit estimator still remains consistent, but the estimated standard errors will have incorrect size and the inference will be misleading. We thus use the time span between the proposals as well as the dimensionality of the policy space to measure these environmental factors of the conciliation process.

\section{DATA AND MEASUREMENT: CONFLICTS AND SUCCESS}

For our empirical analysis of power and success of the two institutional actors in the EU conciliation process, we gathered data using a standardized questionnaire for interviewing experts about the conflicts in the conciliation process since the entry into force of the Amsterdam treaty in 1999. We were looking for people that had considerable insight into the conciliation process, meaning that they had to know the situation in the preparatory stages, such as the set of contested issues discussed in the first and second reading of the dossier and the trialogue meetings as well as the point locations of the actors involved. ${ }^{51}$ Our main interview targets were the rapporteurs, who are the legislative entrepreneurs in the codecision procedure. ${ }^{52}$ The rapporteur co-ordinates the parliamentary view on a legislative proposal and is the primary contact person for the Council and the Commission. ${ }^{53}$ In the event that the rapporteur was not available, we interviewed the administrative adviser if she confirmed having been deeply involved in the preparation and co-ordination process of the proposal. If this was not the case, we contacted the responsible legislative administrator from the conciliation secretariat of the European Parliament for an interview. These administrators often know the details of the conciliation process because they help the office of the rapporteur responsible for the proposal in drafting compromise texts. Moreover, they have close contacts with their administrative colleagues in the Council and the Commission. Additional information on other variables was

50 Mark A. Pollack, 'Delegation, Agency, and Agenda Setting in the European Community', International Organization, 51 (1997), 99-134, pp. 126ff.; Mark A. Pollack, The Engines of European Integration: Delegation, Agency, and Agenda Setting in the EU (Oxford: Oxford University Press, 2003).

51 During the period studied, fifty-four dossiers passed through the conciliation committee. Experts for all fifty-four dossiers could be located and interviewed, and of them thirty-four interview partners were members of the European Parliament (MEPs) and seven were MEP advisers. The remaining thirteen interviews were conducted with legislative administrators from the parliamentary conciliation committee secretariat that was responsible for the dossier.

${ }^{52}$ Benedetto, 'Rapporteurs as Legislative Entrepreneurs'.

53 Corbett, Jacobs and Shackleton, The European Parliament. 
collected through a document analysis of reports from the parliamentary conciliation secretariat. ${ }^{54}$

Our strategy of relying on the expert judgement of individuals associated with the European Parliament may raise concerns about biased data regarding the set of selected issues, the location of actors' positions and distances to the status quo and the outcome. For validation, several steps were performed. In order to cross-check the selected set of issues we used information published in the Activity Reports of the EP Conciliation Secretariat and the Legislative Observatory. The Activity Reports contain information about the process and content of conciliation for all co-decision proposals, and the Legislative Observatory (OEIL) provides detailed online information on EP working activities and lists short summaries of all stages of the co-decision procedure. Any issue recorded in Table A1 in the appendix as identified by our interviewees is either mentioned in the Activity Reports or in the OEIL summary of the conciliation committee negotiations. ${ }^{55}$ This suggests that our interviewees had sufficient insight into the conciliation process to identify the set of contested issues correctly. Upon closer inspection, these documents also provide information about the estimates of eleven cases dealing with budgetary affairs. Standardizing the budgetary figures on a scale from 0 to 100 , where 100 indicates the highest and 0 the lowest budgetary demand in terms of euros, we are able to confirm exactly the point location of the European Parliament, Council, Commission, status quo and legislative outcome (15 per cent of all seventy-three cases).

Another source of information is provided by the data of the DEU project, which studies more than sixty proposals initiated by the Commission before January 2001 and after the Treaty of Amsterdam came into effect. Twenty-six DEU proposals were introduced under co-decision procedure (twenty-one under Council qualified majority, five under unanimity), and five of them were negotiated in the conciliation committee under the qualified majority rule, one under unanimity. ${ }^{56}$ The DEU data contains information on the point locations of the European Parliament, the Commission, the status quo and the legislative outcome on a scale ranging from 0 to 100 for each issue. The main difference between the two datasets is that the DEU researchers asked for the positions of the fifteen member states before the common Council position had been formulated, while we were interested in the Council's collective position during the conciliation process. ${ }^{57}$ Another important difference is that the DEU experts were mainly affiliated with member-state institutions (sixty-nine out of 125, only four came from the European Parliament), while our interview targets were the parliamentary rapporteurs.

Using the DEU data for the contested issues negotiated in the conciliation committee, we find a surprisingly high similarity regarding the point locations of the European

${ }^{54}$ The parliamentary conciliation secretariat's documents that were consulted were the Activity Reports for the years 1999-2000, 2000-01, 2001-02. The variables for the Council presidency and the political party of the rapporteur are based on information from these documents.

55 Parliamentarian Conciliation Secretariat, Activity Report 1999-2000 (2000), at: http://www.europarl.eu.int/ code/information/activity_reports/activity_report_2000_en.pdf (23.03.2002); Parliamentarian Conciliation Secretariat, Activity Report 2000-2001 (2001) at: http://www.europarl.eu.int/code/information/activity_reports/ activity_report_2001_en.pdf (23.03.2002); Parliamentarian Conciliation Secretariat, Activity Report 2001-2002 (2002): at: http://www.europarl.eu.int/code/information/activity_reports/activity_report_2002_ en.pdf (20.06.2002).

56 Thomson, Stokman, Achen and König, eds, The European Union Decides.

57 Javier Arregui, Frans N. Stokman and Robert Thomson found that Council members change their position over time (European Union Politics, 1 (2004), 47-72). 
TABLE 2 Distances Between the Measures of the DEU and Our Data

\begin{tabular}{|c|c|c|c|c|c|c|c|}
\hline $\begin{array}{l}\text { Legislative } \\
\text { dossier }\end{array}$ & Issue & EP & Commission & $\begin{array}{l}\text { Status } \\
\text { Quo }\end{array}$ & Outcome & $\begin{array}{l}\text { Council } \\
\text { minority }\end{array}$ & $\begin{array}{l}\text { Council } \\
\text { Pivot }\end{array}$ \\
\hline $\begin{array}{l}\text { Droite de } \\
\text { suite }\end{array}$ & $\begin{array}{l}\text { Resale } \\
\text { right }\end{array}$ & $\begin{array}{l}\text { Almost } \\
\text { Perfect, } \\
10\end{array}$ & $\begin{array}{l}\text { Almost } \\
\text { Perfect, } 12\end{array}$ & $\begin{array}{l}\text { Perfect, } \\
0\end{array}$ & $\begin{array}{l}\text { Almost } \\
\text { Perfect, } \\
25\end{array}$ & $\begin{array}{l}\text { Perfect, } \\
0\end{array}$ & 72 \\
\hline $\begin{array}{l}\text { Takeover } \\
\text { bids }\end{array}$ & $\begin{array}{l}\text { Defensive } \\
\text { measures }\end{array}$ & $\begin{array}{l}\text { Perfect, } \\
0\end{array}$ & $\begin{array}{l}\text { Perfect, } \\
0\end{array}$ & $\begin{array}{l}\text { Perfect, } \\
0\end{array}$ & Missing & 100 & $\begin{array}{l}\text { Perfect, } \\
0\end{array}$ \\
\hline Tobacco & $\begin{array}{l}\text { Health } \\
\text { warnings }\end{array}$ & $\begin{array}{l}\text { Perfect, } \\
0\end{array}$ & $\begin{array}{l}\text { Almost } \\
\text { Perfect, } 20\end{array}$ & $\begin{array}{l}\text { Missing, } \\
0\end{array}$ & $\begin{array}{l}\text { Perfect, } \\
5\end{array}$ & $\begin{array}{l}\text { Almost } \\
\text { Perfect, } \\
25\end{array}$ & 50 \\
\hline Tobacco & $\begin{array}{l}\text { Misleading } \\
\text { descrip- } \\
\text { tions }\end{array}$ & $\begin{array}{l}\text { Perfect, } \\
0\end{array}$ & $\begin{array}{l}\text { Almost } \\
\text { Perfect, } 20\end{array}$ & Missing & $\begin{array}{l}\text { Almost } \\
\text { Perfect, } \\
15\end{array}$ & $\begin{array}{l}\text { Perfect, } \\
0\end{array}$ & $\begin{array}{l}\text { Almost } \\
\text { Perfect, } \\
25\end{array}$ \\
\hline Socrates II & Budget & $\begin{array}{l}\text { Perfect, } \\
0\end{array}$ & $\begin{array}{l}\text { Almost } \\
\text { Perfect, } 24\end{array}$ & $\begin{array}{l}\text { Perfect, } \\
0\end{array}$ & $\begin{array}{l}\text { Perfect, } \\
1\end{array}$ & $\begin{array}{l}\text { Perfect, } \\
2\end{array}$ & $\begin{array}{l}\text { Almost } \\
\text { Perfect, } \\
18\end{array}$ \\
\hline Socrates II & $\begin{array}{l}\text { Review } \\
\text { clause }\end{array}$ & $\begin{array}{l}\text { Perfect, } \\
0\end{array}$ & Perfect, 0 & Missing & 50 & $\begin{array}{l}\text { Perfect, } \\
0\end{array}$ & $\begin{array}{l}\text { Perfect, } \\
0\end{array}$ \\
\hline $\begin{array}{l}\text { Motor } \\
\text { insurance }\end{array}$ & Scope & $\begin{array}{l}\text { Almost } \\
\text { Perfect, } \\
15\end{array}$ & $\begin{array}{l}\text { Almost } \\
\text { Perfect, } 21\end{array}$ & $\begin{array}{l}\text { Almost } \\
\text { Perfect, } \\
15\end{array}$ & $\begin{array}{l}\text { Almost } \\
\text { Perfect, } \\
13\end{array}$ & $\begin{array}{l}\text { Perfect, } \\
4\end{array}$ & $\begin{array}{l}\text { Perfect, } \\
4\end{array}$ \\
\hline
\end{tabular}

Note: 'Perfect' means a difference between 0 and 5 in the DEU and Conciliation estimation of policy positions. 'Almost Perfect' means a difference of 6 to 25.

Parliament, Commission, status quo, outcome and the Council Pivot, which we calculated in order to compare it with our collective Council position: as shown in Table 2, the point location of fifteen positions is the same (deviation of $0-5$ ), thirteen positions are almost identical (deviation of 6-25), four positions are not comparable due to missing values, and only three measures indicate a large deviation (50, 50 and 70). On closer inspection of these three deviating cases, two of them list a scant Council qualified majority position, while the minority position is again almost identical with our Council estimate. This suggests that the Council may have introduced the minority position in the bargains of the conciliation process.

The only remaining deviant point estimate between our and the DEU data is the outcome of the review clause issue of the Socrates II proposal. Our indicator suggests a split-the-difference compromise between the Council (0) and the European Parliament (100), while the DEU estimate indicates total success of the European Parliament. Unfortunately, neither OEIL nor the Activity Reports provide any further information about the outcome of the Socrates II proposal. However, since our split-the-difference estimate of the European Parliament's bargaining success is more conservative than the DEU assessment by a Council expert, we do not find evidence for a possible parliamentary bias by interviewing the rapporteurs in favour of the European Parliament.

In sum, our evaluation of the point locations of the European Parliament, Commission, status quo, outcome and the Council Pivot reveals a surprisingly high cross-validation between the documents, the DEU and our data, even though experts have different institutional affiliations. In addition to the eleven budgetary issues, which completely 
confirm the point location of the European Parliament, the Council, the Commission, the status quo and the legislative outcome, thirty out of thirty-one point estimates of the DEU and our data perfectly or almost perfectly coincide. This consistency of point estimates suggests a high reliability and cross-validity of the two datasets, which is relatively independent from the interviewees' institutional affiliation.

The interviews began by identifying the underlying conflict dimension of the conciliation bargain. We asked the interviewees to locate the positions of the Council, the European Parliament, the status quo and outcome on a scale from 0 to 100 . We can interpret the distance between European Parliament and Council as the conciliation bargaining space because the status quo is never located between the two institutional actors. At first sight, this suggests that only solvable cases are negotiated in the conciliation process, but the high adoption rate of EU legislative proposals indicates that unsolvable cases hardly reach the legislative agenda. Comparing the individual distances of the institutional actors to the outcome, we ordered the bargaining success according to three categories: Council wins, European Parliament wins and tied. This is our ordered dependent variable, and we want to examine which factors explain these outcomes in the conciliation bargains. The ordering will allow us to specify how these factors affect each outcome. For this purpose, we use measures for their individual distance to the status quo, the preference cohesiveness of the European Parliament and the Council and their impatience. ${ }^{58} \mathrm{We}$ are also interested in the role of the Council presidency and the party group of the rapporteur, the impact of support by the Commission, and the influence of environmental factors, such as the number of policy dimensions and the time between the proposals. Table 3 summarizes our variables, their range and coding of the values as well as their frequencies.

We were able to gather information on almost all conflicts discussed in the conciliation committee from the beginning of the Amsterdam version of co-decision in May 1999 until the end of July 2002. Missing values obliged us to exclude only one case from our sample. The descriptive statistics of our dependent variable show that

- the European Parliament won in 56 per cent of cases,

- the Council in only 26 per cent, and

- the European Parliament and the Council tied in 18 per cent of all cases.

\section{Status quo}

The explanatory variable SQdist measures the importance of the status quo location for the conciliation committee bargaining outcome. The variable was coded 1 when the European Parliament was located closer to the status quo, 0 when no information on the status quo was reported and -1 when the Council was closer to the status quo. In only one case was the European Parliament located closer to the status quo, which confirms the findings of other empirical studies on the more integrationist position of the European Parliament in legislative decision making. ${ }^{59}$

${ }^{58}$ Due to the nature of the policy space we only distinguish whether the Council or the European Parliament is closer to the status quo, or whether no information on the location of the status quo was recorded.

59 Thomas König and Mirja Pöter, 'Examining the EU Legislative Process: The Relative Importance of Agenda Setting and Veto Power', European Union Politics, 2 (2001), 329-51; Thorsten Selck, 'On the Dimensionality of European Union Legislative Decision-Making', Journal of Theoretical Politics, 16 (2004), 203-23. 
TABLE 3 Dependent and Explanatory Variables

\begin{tabular}{|c|c|c|c|c|}
\hline Variables & Content & Range & Coding & Frequency \\
\hline DV & $\begin{array}{l}\text { Dependent Variable: } \\
\text { Conciliation committee } \\
\text { bargaining success }\end{array}$ & $\begin{array}{r}-1 \\
0 \\
1\end{array}$ & $\begin{aligned}-1 & =\text { Council wins } \\
0 & =\text { Tie } \\
1 & =\text { EP wins }\end{aligned}$ & $\begin{aligned}-1 & =19 \\
0 & =13 \\
1 & =41\end{aligned}$ \\
\hline SQdist & Distance to the SQ & $\begin{array}{r}-1 \\
0 \\
1\end{array}$ & $\begin{aligned}-1 & =\text { Council closer to SQ } \\
0 & =\text { no SQ } \\
1 & =\text { EP closer to SQ }\end{aligned}$ & $\begin{aligned}-1 & =30 \\
0 & =42 \\
1 & =1\end{aligned}$ \\
\hline Coh_ep_m & $\begin{array}{l}\text { Cohesiveness of EP } \\
\text { (metric) }\end{array}$ & $0-100$ & $\begin{aligned} 100 & =\text { homogeneous } \\
75 & =\text { minor difference in } \\
& \text { preference } \\
50 & =\text { moderate difference } \\
& \text { in preference } \\
25= & \text { major difference in } \\
& \text { preference } \\
0= & \text { heterogeneous }\end{aligned}$ & $\begin{aligned} 100 & =50 \\
75 & =14 \\
50 & =2 \\
25 & =6 \\
0 & =1\end{aligned}$ \\
\hline Coh_co_m & $\begin{array}{l}\text { Cohesiveness of Council } \\
\text { (metric) }\end{array}$ & $0-100$ & $\begin{aligned} 100 & =\text { homogeneous } \\
75= & \text { minor difference in } \\
& \text { preference } \\
50= & \text { moderate difference } \\
& \text { in preference } \\
25= & \text { major difference in } \\
& \text { preference } \\
0= & \text { heterogeneous }\end{aligned}$ & $\begin{aligned} 100 & =10 \\
75 & =23 \\
50 & =17 \\
25 & =18 \\
0 & =5\end{aligned}$ \\
\hline Df_ep_m & $\begin{array}{l}\text { Discount rate EP } \\
\text { (metric) }\end{array}$ & $0-100$ & $\begin{aligned} 0 & =\text { indifferent to time } \\
25 & =\text { minor interest in time } \\
50 & =\text { moderate interest in } \\
& \text { time } \\
75= & \text { major interest in time } \\
100= & \text { very high in time }\end{aligned}$ & $\begin{aligned} 0 & =31 \\
25 & =29 \\
50 & =5 \\
75 & =1 \\
100 & =7\end{aligned}$ \\
\hline Df_co_m & $\begin{array}{l}\text { Discount rate Council } \\
\text { (metric) }\end{array}$ & $0-100$ & $\begin{aligned} 0= & \text { indifferent to time } \\
25= & \text { minor interest in time } \\
50= & \text { moderate interest in } \\
& \text { time } \\
75= & \text { major interest in time } \\
100= & \text { very high interest in } \\
& \text { time }\end{aligned}$ & $\begin{aligned} 0 & =24 \\
25 & =9 \\
50 & =12 \\
75 & =7 \\
100 & =21\end{aligned}$ \\
\hline Coupres & $\begin{array}{l}\text { Voting pattern of } \\
\text { Council presidency }\end{array}$ & $\begin{array}{l}0 \\
1\end{array}$ & $\begin{aligned} 0= & \text { Council presidency } \\
& \text { regular voting } \\
1= & \text { Council presidency } \\
& \text { outlying voting }\end{aligned}$ & $\begin{array}{l}0=43 \\
1=30\end{array}$ \\
\hline Rapport & $\begin{array}{l}\text { Party group membership } \\
\text { of rapporteur }\end{array}$ & $\begin{array}{l}0 \\
1\end{array}$ & $\begin{array}{l}0=\text { other parties in EP } \\
1=\text { EPP-ED and PES }\end{array}$ & $\begin{array}{l}0=29 \\
1=44\end{array}$ \\
\hline Comsup_m & $\begin{array}{l}\text { Commission support of } \\
\text { EP or Council }\end{array}$ & $\begin{array}{l}-100- \\
100\end{array}$ & $\begin{aligned}-100= & \text { Commission } \\
& \text { supports EP } \\
0= & \text { No Commission } \\
& \text { support } \\
100= & \text { Commission } \\
& \text { supports Council }\end{aligned}$ & $\begin{aligned}-100 & =41 \\
0 & =8 \\
100 & =24\end{aligned}$ \\
\hline Dimen & $\begin{array}{l}\text { Dimensionality of } \\
\text { proposal }\end{array}$ & $\begin{array}{l}0 \\
1\end{array}$ & $\begin{array}{l}0=\text { one-dimensional } \\
1=\text { multidimensional }\end{array}$ & $\begin{array}{l}0=37 \\
1=36\end{array}$ \\
\hline Month & Time trend in month & $1-37$ & $i=$ month of the vote & Month \\
\hline
\end{tabular}




\section{Preferences}

The variable on cohesiveness Coh_ep_m (coh_co_m) indicates the cohesiveness of the institutional actors' preferences. It ranges between 100 for the most cohesive and 0 for the most non-cohesive preferences. The European Parliament had the most cohesive preference in fifty cases, and the Council had it in only ten cases. This corresponds with the findings on EP cohesiveness of Kreppel, Hix et al. and Bailer and Schneider. ${ }^{60} \mathrm{We}$ also investigated the impatience of the two institutional actors $\left(D f \_p \_m, D f_{-} c o \_m\right)$, and whether they were indifferent to time or had a very high interest in a fast decision. The European Parliament generally had a lower discount rate and was more patient than the Council.

\section{Institutions}

Using Mattila and Lane's findings of Council voting patterns, we divided the member states into two voting groups, according to who held the Council presidencies (Coupres) during our period of study. ${ }^{61}$ Member states, such as Belgium, Finland, France, Portugal, usually voted with the majority of the member states in the Council. They were assigned the value 0 , while Sweden and Spain had a conservative outlier voting pattern and were assigned a value of 1 . The variable rapport is the party group dummy variable for the European Parliament. It has the value of 1, if the rapporteur was a member of the EPP-ED or the PES. This was the case 60 per cent of the times. We interpret the distance between the European Parliament (Council) and the Commission as a measure of Commission support for the respective institutional actor. The variable Comsup_m indicates the distance between the Commission and the respective actor, either the European Parliament or the Council. In forty-one cases, the Commission was closer to the European Parliament, while the Commission supported the Council in only twenty-four of all cases. We include the variables dimen and month as control variables. They measure the dimensionality of the policy space of a proposal and the time trend in the month between the proposals.

\section{STATISTICAL ANALYSIS AND FINDINGS ON EU CONCILIATION BARGAINS}

In our statistical analysis we use an ordered probit model, where the bargaining power of the European Parliament relative to that of the Council is treated as a continuous latent variable, $Y^{*}$, with an observable ordered trichotomous counterpart, $Y$. The latent model is given by

$$
Y_{i}^{*}=X_{i} \beta+\varepsilon_{i} \quad i=1, \ldots, n
$$

where $X_{i}$ is a vector of explanatory variables (excluding an intercept term) and $\varepsilon_{i}$ a standard normally distributed error term. The probability of observing the three possible

${ }^{60}$ Kreppel, 'Rules, Ideology and Coalition Formation in the European Parliament'; Hix, Noury and Roland, 'Understanding the European Parliament'; Stephanie Bailer and Gerald Schneider, 'When Words Matter: Informal Rules and the Enlargement Debate', in Bernard Steunenberg and Jacques Thomassen, eds, The European Parliament - Moving Toward Democracy in the EU (Lanham, Md.: Rowman \& Littlefield, 2002), pp. 139-61.

61 Mattila and Lane, 'Why Unanimity in the Council?' 
outcomes (Council wins: $Y_{i}=-1$, Tie: $Y_{i}=0$ and European Parliament wins: $Y_{i}=1$ ) are given by:

$$
\operatorname{Pr}\left[Y_{i}=j \mid X_{i}\right]= \begin{cases}\Phi\left(\mu_{1}-X_{i}^{\prime} \beta\right) & j=-1 \\ \Phi\left(\mu_{2}-X_{i}^{\prime} \beta\right)-\Phi\left(\mu_{1}-X_{i}^{\prime} \beta\right) & j=0 \\ 1-\Phi\left(\mu_{2}-X_{i}^{\prime} \beta\right) & j=1\end{cases}
$$

where $\Phi(\cdot)$ denotes the cdf of the standard normal; $\mu_{1}$ and $\mu_{2}$ are the two threshold parameters. ${ }^{62}$ A positive sign on a $\beta$ coefficient reflects an increase of the probability that the European Parliament succeeds in the conciliation bargain due to an increase of the corresponding explanatory variable. The model is estimated by maximum likelihood using our own Gauss-Maxlik routine. Table 4 reports on the estimation results. The standard errors are computed as quasi-maximum likelihood standard errors (heteroscedasticity robust standard errors) using the sandwich formula to account for a potential general misspecification.

According to Table 4, the closeness to the status quo, the preference cohesiveness of the two institutional actors, the dimensionality of the proposal and the Commission's support significantly matter for bargaining success. Before interpreting these findings,

TABLE 4 Ordered Probit Model of EU Conciliation Committee Bargaining Success

\begin{tabular}{|c|c|c|c|c|}
\hline & & & Estimates & $\begin{array}{l}\text { Standard } \\
\text { deviation }\end{array}$ \\
\hline Closeness to SQ (SQdist) & & & $0.8467 * *$ & 0.3335 \\
\hline Cohesiveness of EP (Coh ep $m)$ & & & $0.0160 * *$ & 0.0064 \\
\hline Cohesiveness of Council $(\mathrm{Co} \bar{h} \mathrm{co}$ m) & & & $-0.0101 *$ & 0.0056 \\
\hline Discount rate EP $\left(D f e p \_m\right)$ & & & -0.0061 & 0.0056 \\
\hline Discount rate Council̄ $\left(\overline{D f} \_\right.$cou_m $)$ & & & -0.0026 & 0.0039 \\
\hline Council presidency (Coupres) & & & 0.4814 & 0.4433 \\
\hline Political party of rapporteur (Rapport) & & & 0.1935 & 0.3194 \\
\hline Commission support (Comsup_m) & & & $-0.0055^{*}$ & 0.0031 \\
\hline Dimensionality of proposal (Dimen) & & & $-0.6833 *$ & 0.3629 \\
\hline Month (MONATE) & & & 0.0042 & 0.0240 \\
\hline Threshold 1 & & & -0.3963 & 0.8446 \\
\hline Threshold 2 & & & 0.2349 & 0.8573 \\
\hline Mean log likelihood & & -0.8212 & & \\
\hline Pseudo $R^{2}$ & & 0.3338 & & \\
\hline GMT test of serial correlation of order 1 & 0.2662 & & $p$-value: 0.6059 & \\
\hline Box Pierce Q-Test of correlation of order 1 & 0.2545 & & p-value: 0.6139 & \\
\hline Conditional Moment Test & 0.4906 & & p-value: 0.9999 & \\
\hline
\end{tabular}

Sample period: May 1999 to July 2002, number of observations 73. ***Significant at the $1 \%$ level, **Significant at the $5 \%$ level, *Significant at the $10 \%$ level.

${ }^{62}$ Note that we are using a specification without intercept such that two threshold parameters can be identified. The parameter estimates can be easily transformed corresponding to an equivalent specification with one threshold and an intercept. 
we discuss whether the independence assumption underlying standard quantal response models might be questioned since the outcome of the bargaining process may well depend on the outcome of the previous bargaining round(s). If the independence assumption on the error term distribution is violated, the ordered probit estimator still remains consistent, but the estimated standard errors will be incorrectly sized and the inference will be misleading. We therefore test for first order serial correlation in the error term process using the test proposed by Gourieroux, Monfort and Trognon (GMT). ${ }^{63}$

Secondly, the mean function of the latent model defined in (1) may suffer from dynamic misspecification by ignoring true state dependence (lag values of the latent) dependent variable. In order to check for this possibility of dynamic misspecification we use a conditional moment test to test for the null hypothesis of independent errors against the alternative (null) of general dependence ${ }^{64}$ Both the GMT test for serial correlation as well as the conditional moment test do not indicate any type of dynamic misspecification. In order to examine a potential systematic change in the relative bargaining power of the institutional actors, we also added a time trend (month) to the mean function. In none of the specifications did this trend turn out to be significant. Thus, there is no empirical evidence that one of the institutional actors could increase its bargaining power during the period under investigation. This means that we do not find evidence for the linkage of the proposals and their outcomes over time.

The sign of $\beta$ only provides insight on the direction of the effect for the two extreme outcome probabilities (Council wins, European Parliament wins). We therefore plot the effect of a given metric variable on the three outcome probabilities for the full range of possible values holding all other covariates at their sample means. In our application this is possible because the range of the metric variables used is bounded between 0 and 100, or -100 and 100. Hence we can infer the effect of the covariate of interest on the 'Tie' category as well as on the magnitude of the outcome probabilities over the full range of values of the covariate. Figures 2, 3 and 4 illustrate our findings of the significant metric variables.

Upon closer inspection of the significant metric variables, Figure 2 shows that the cohesiveness of the Council does not dramatically change member-state success and tie. Parliamentary success continuously increases with the decreasing homogeneity of member-state preferences. In the event of highly non-cohesive member-state preferences, the European Parliament's chance of winning is almost 0.8. A different picture is provided by Figure 3 on the cohesiveness of the parliamentary preference distribution. Not only does the Council suffer from parliamentary cohesiveness but also the success of the European Parliament increases at almost the same rate. A very non-cohesive European Parliament has a winning probability of about 0.15 , which grows in the event of parliamentary cohesiveness to a chance of about 0.65 . At the same time, Council wins continuously decrease with a higher parliamentary cohesiveness from about 0.8 to almost 0.12 . Figure 4 finally illustrates the effect of Commission support by combining parliamentary closeness ranging from 0 to -100 with Council closeness from 0 to 100 . The results on the positive side of the scale show that the probability of the European Parliament winning

${ }^{63}$ Christian Gourieroux, Alain Monfort and Alain Trognon, 'A General Approach to Serial Correlation', Econometric Theory, 1 (1985), 315-40.

${ }^{64}$ Whitney K. Newey, 'Maximum Likelihood Specification Testing and Conditional Moment Tests', Econometrica, 53 (1985), 1047-70. 


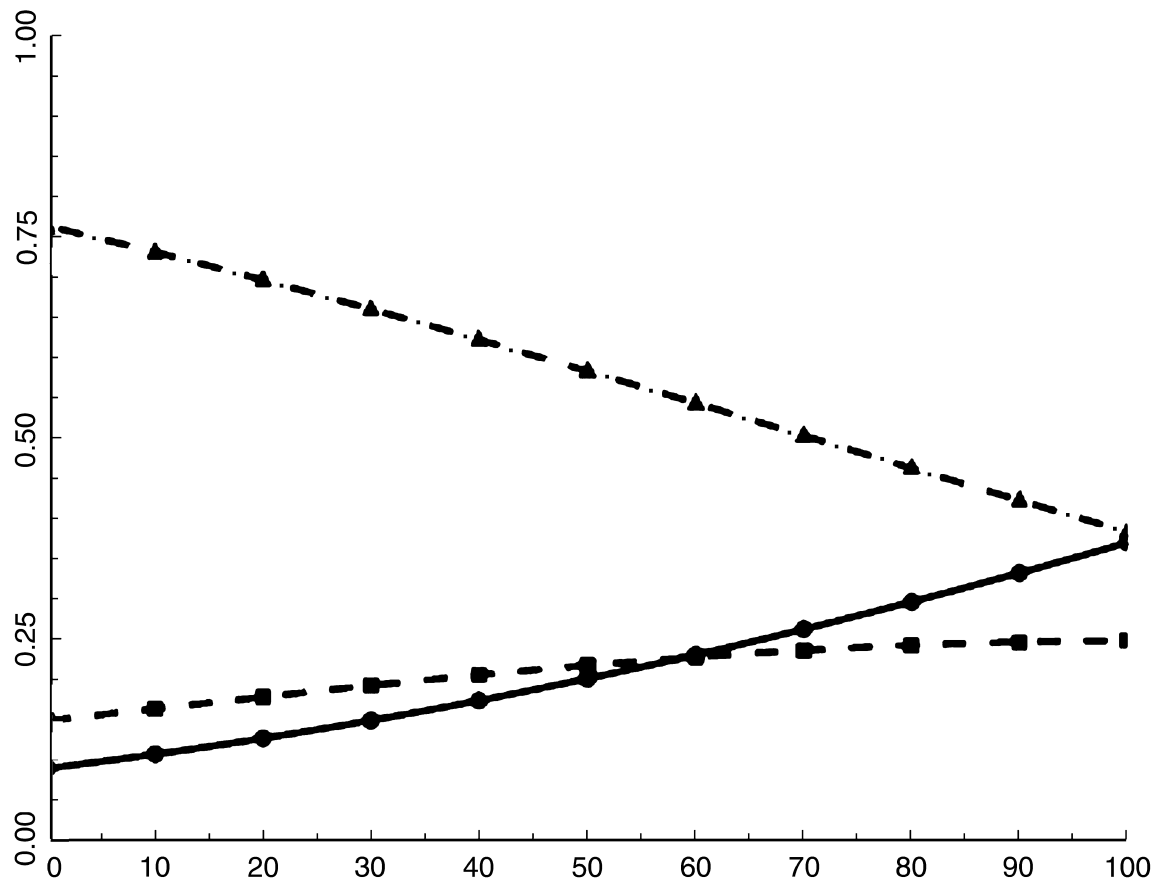

Fig. 2. Effect of Council cohesiveness (Coh_co_m) on the probability that the Council wins (circles), the probability of a tie (squares) and the probability that the European Parliament wins (triangles), evaluated at the mean of the remaining regressors

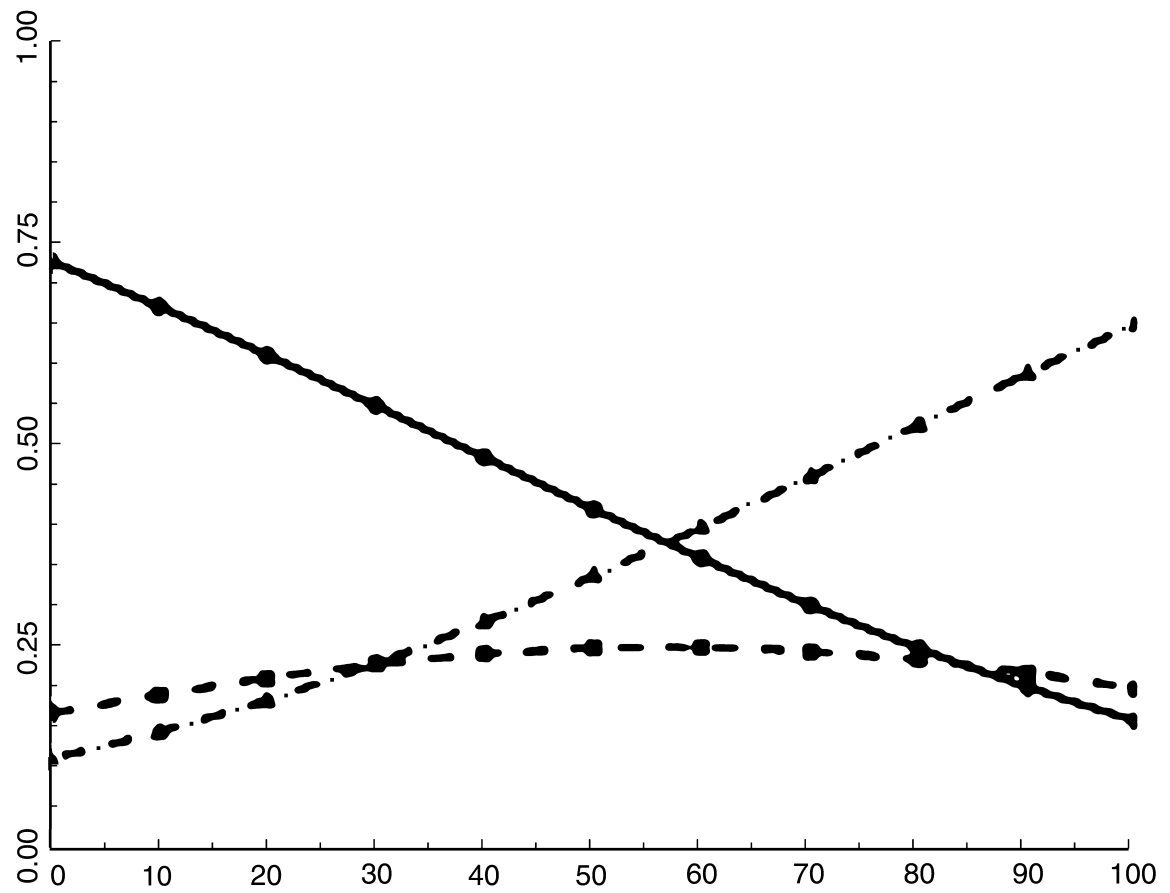

Fig. 3. Effect of EP cohesiveness (Coh_ep_m) on the probability that the Council wins (circles), the probability of a tie (squares) and the probability that the European Parliament wins (triangles), evaluated at the mean of the remaining regressors 


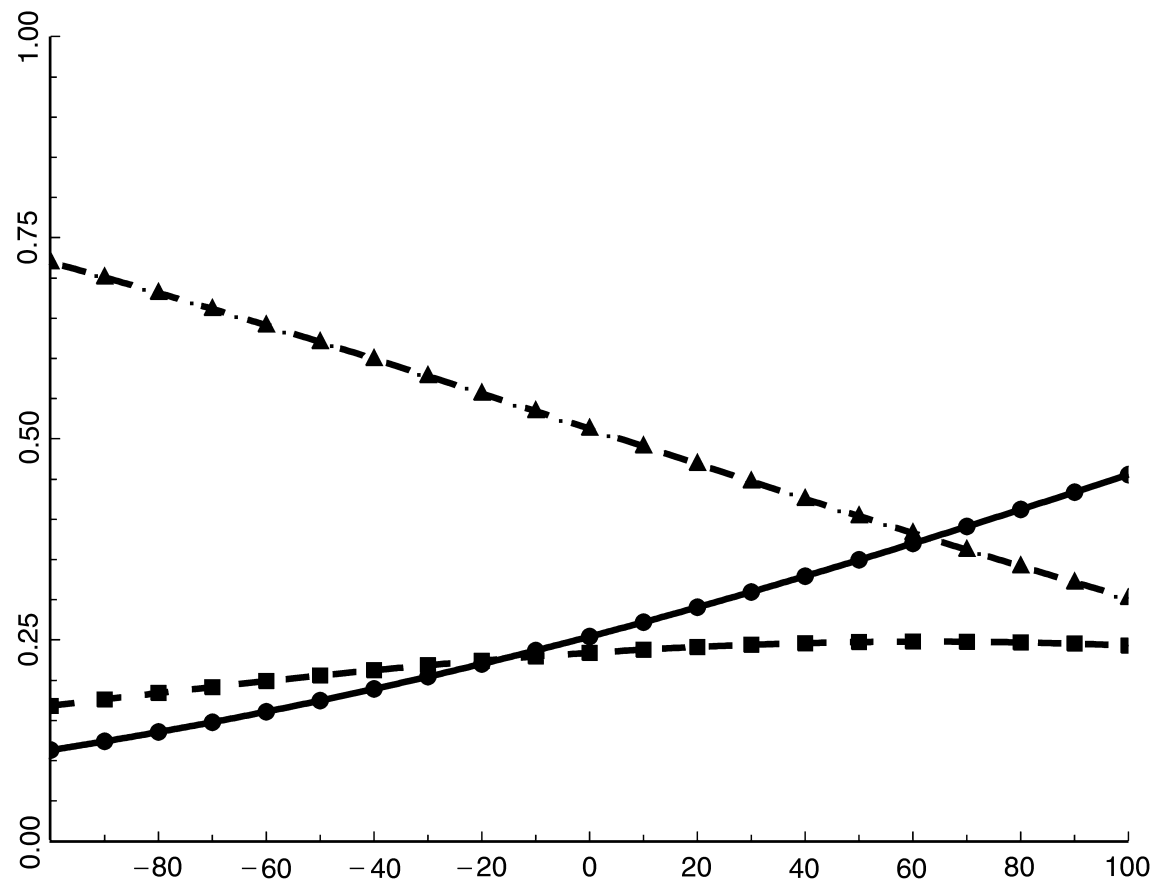

Fig. 4. Effect of Commission support (Comsu-p) on the probability that the Council wins (circles), the probability of a tie (squares) and the probability that the European Parliament wins (triangles), evaluated at the mean of the remaining regressors

is even higher if the Council is slightly supported by the Commission. Even if the Commission supports the Council more than half way $(+60)$, the probability of parliamentary success is higher (0.45) than the Council's likelihood of winning (0.35). However, the Council's probability of winning is continuously increased by Commission support.

\section{CONCLUSION}

This study offers a statistical analysis of the conciliation committee bargains in the European Union, which effectively settle almost all solvable bicameral conflicts between the Council and the European Parliament. While scholars commonly agree that the European Parliament has gained power under co-decision procedure, the impact of the conciliation process had remained unclear. Our analysis sheds light on the conciliation process by examining the power of the institutional actors and the factors explaining their bargaining success. We gathered data on the collective positions of the Council and European Parliament in order to examine the winners and losers of the conciliation process. More specifically, we tested whether the proximity to the status quo, preference cohesiveness, impatience of the two institutional actors, as well as particular features of the conciliation process, such as the presidency and the rapporteur, support of the Commission, dimensionality of the proposal or month of the vote influenced their success.

Before running our statistical analysis, we used several other sources to assess the validity of our interviewees' point estimates. We checked the set of contested issues by document analysis using the Activity Reports of the EP Conciliation Secretariat and the 
Legislative Observatory. These documents also allowed us to identify the point locations for the eleven cases in budgetary affairs. Transforming the budgetary numbers into point positions, we could exactly confirm the point location of the European Parliament, Council, Commission, status quo and legislative outcome (15 per cent of all seventy-three cases). We also used the DEU data to validate these positions on those seven issues negotiated in the conciliation process. Although the two datasets used experts with different institutional affiliation, thirty out of thirty-one point estimates perfectly or almost perfectly coincide. The only different point estimate concerns the location of the outcome of Socrates II, but our split-the-difference outcome of the European Parliament's bargaining success is more conservative than the DEU assessment by a Council expert.

Our statistical findings confirm some theoretical claims, such as the importance of the status quo location (Hypothesis I) and the cohesiveness of the institutional actors' preferences (Hypothesis II). Parliamentary success only slightly increases when the similarity of member-state preferences decreases, while the Council can benefit from a split in parliamentary preferences. This suggests that the European Parliament must form closer coalitions for winning in the conciliation process even if the Council is split. We can also reject some other assumptions, in particular the relevance of impatience (Hypothesis III), of an outlying Council presidency (Hypothesis IV) or an extreme political party of the rapporteur (Hypothesis V), as well as the irrelevance of the Commission in the co-decision procedure (Hypothesis VI). The results for Commission support clearly show that the Commission is still able to influence the success of both the European Parliament and the Council. The European Parliament wins even if the Council is slightly supported by the Commission. However, the Council's probability of winning is continuously increased by Commission support.

This finding of Commission relevance is surprising, as most of the theoretical models exclude the Commission from their analysis of the co-decision procedure due to its lack of agenda-setting power. ${ }^{65}$ According to our results, the Commission seems to have informational advantages and is an active mediator between the two institutional actors. Our analysis also reveals the difficulties in identifying the winners and losers of the conciliation process, because the European Parliament wins most conciliation cases, while the Council is more powerful in the multidimensional ones. In our view, this shows the importance of empirical research on legislative decision making and the particular institutions involved for drawing conclusions on the power distribution in complex legislative arrangements.

Due to the continuous process of expanding the application of the co-decision procedure and the material competencies of the European Union in terms of scope and scale, this bicameral process and the conciliation committee will become more important in the future. Moreover, the European Union has increased its membership from fifteen to twenty-five member states in May 2004 - an enlargement which may increase the conflicts within the Council and between the member states and the European Parliament. Our findings indicate that the European Parliament can benefit from this enlargement if member states have highly heterogeneous preferences. However, if the accession of ten countries from Eastern and Southern Europe implies a higher status quo bias of member states, our analysis suggests that the Council will regain power in the conciliation process.

${ }^{65}$ Steunenberg, 'Codecision and its Reform: A Comparative Analysis of Decision-making Rules in the European Union'; Steunenberg and Dimitrova, Interest, Legitimacy, and Constitutional Choice; Crombez, 'The Treaty of Amsterdam and the Codecision Procedure'; Tsebelis and Garrett, 'Legislative Politics in the European Union'. 


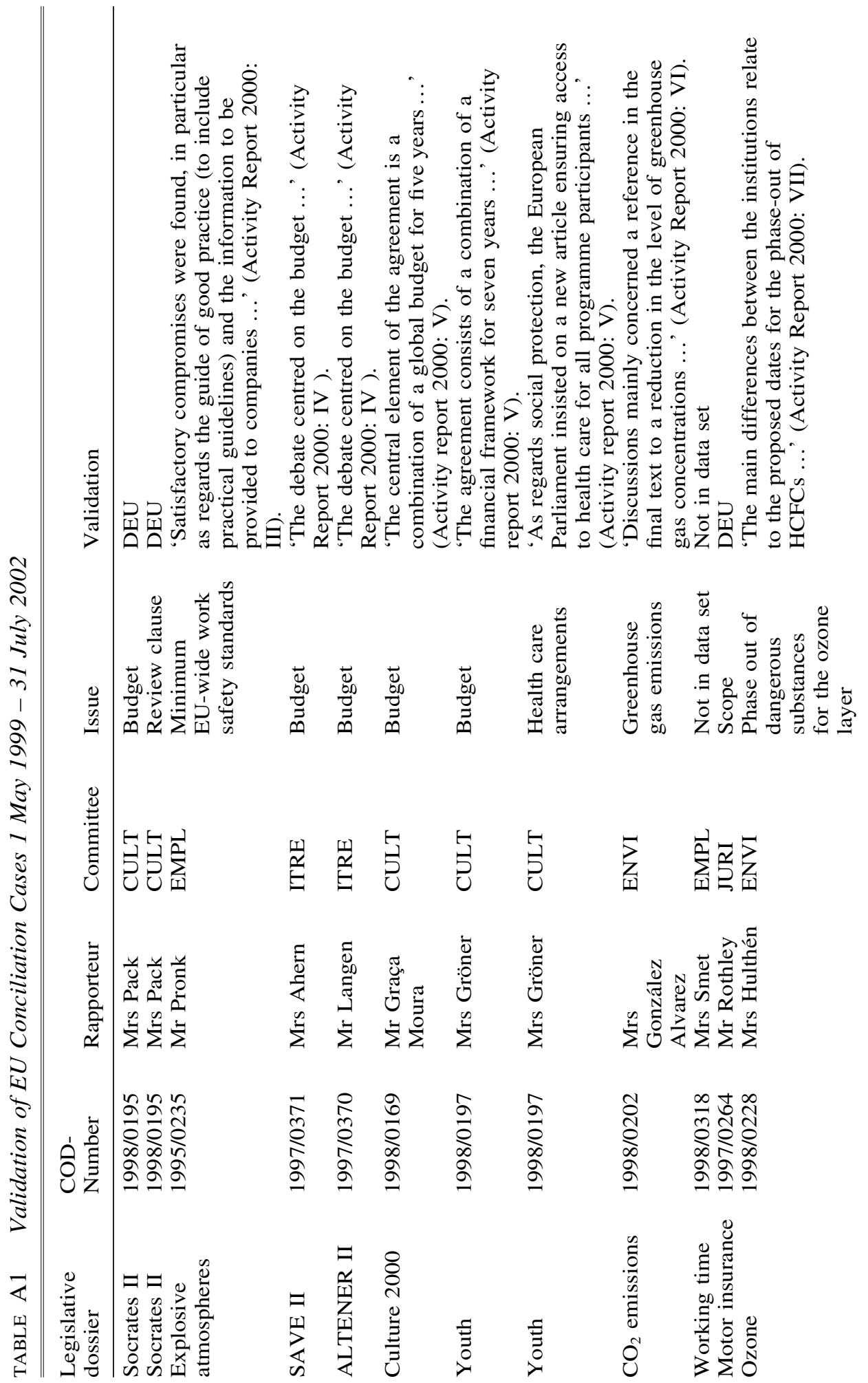




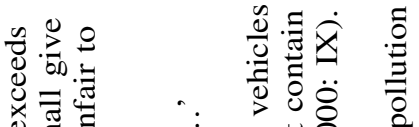

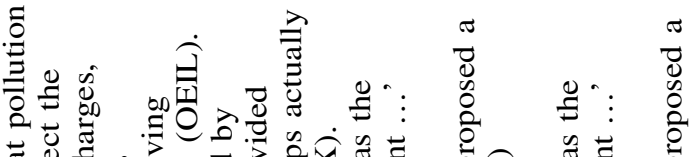

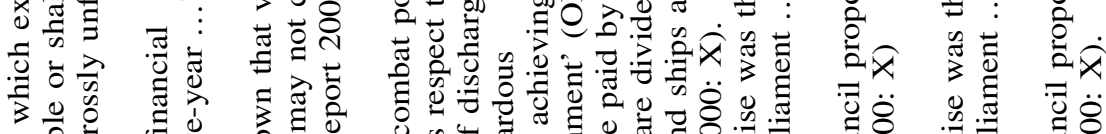

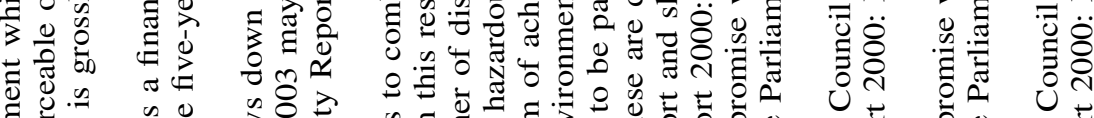

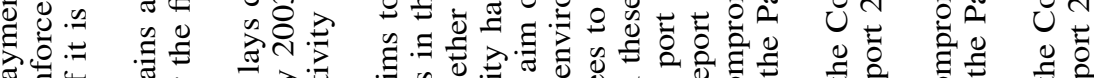

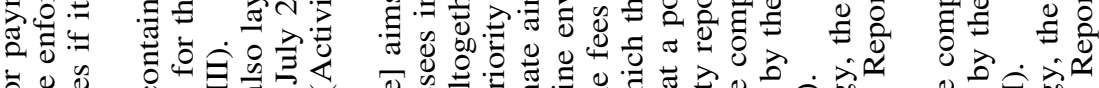

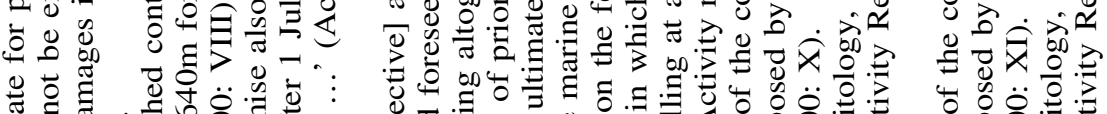

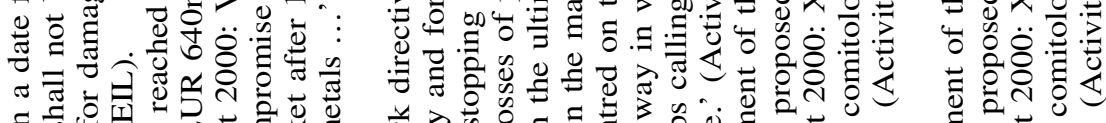

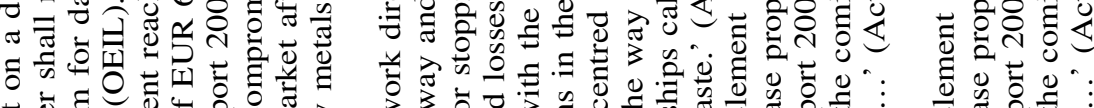

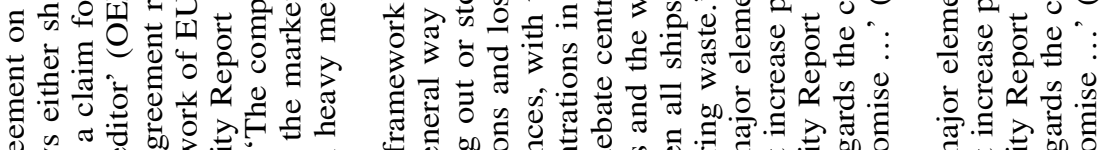

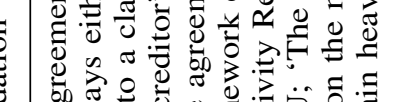

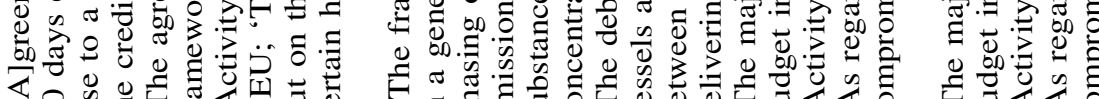

《o

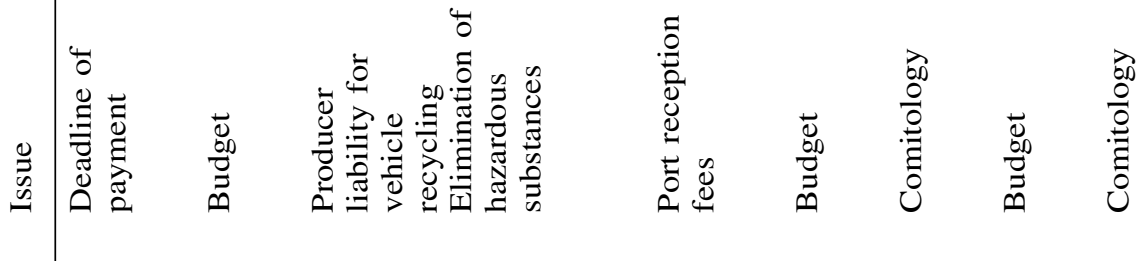

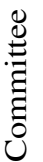

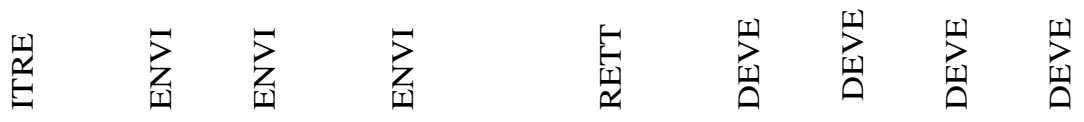

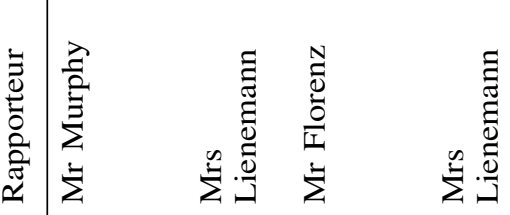

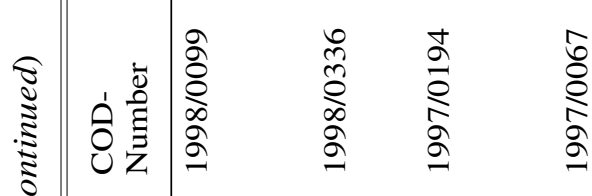

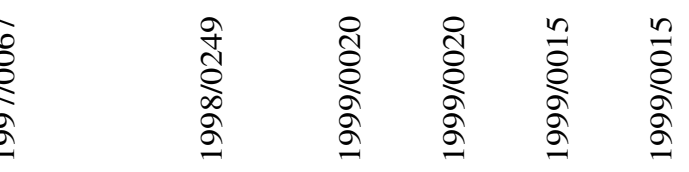

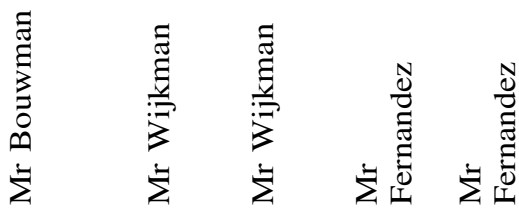

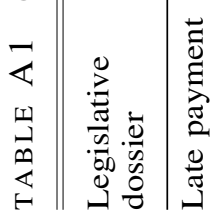

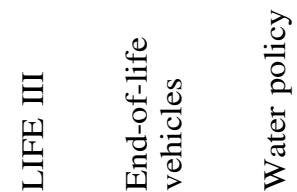

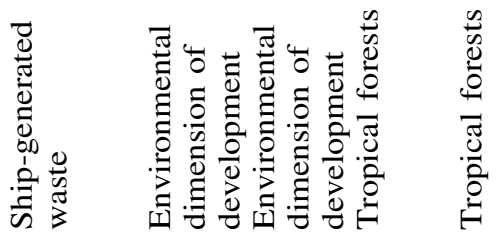




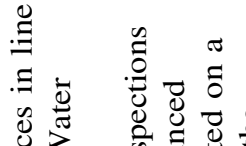

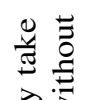

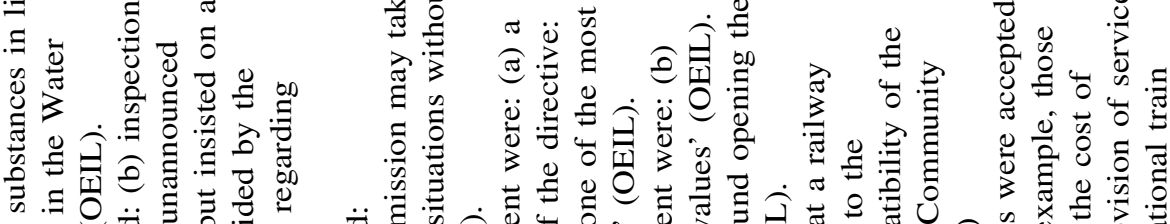

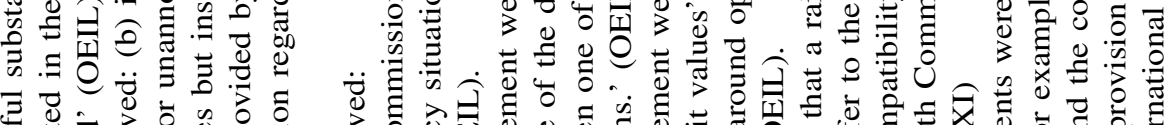

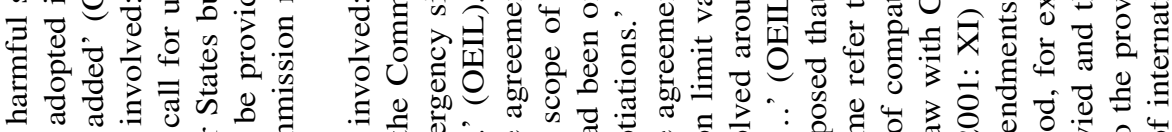

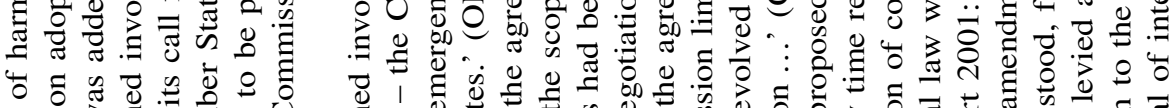

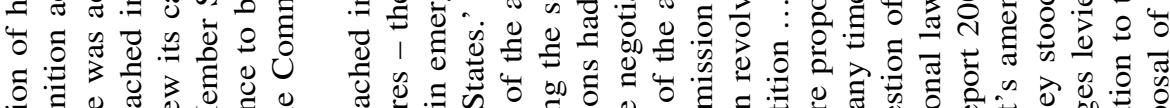

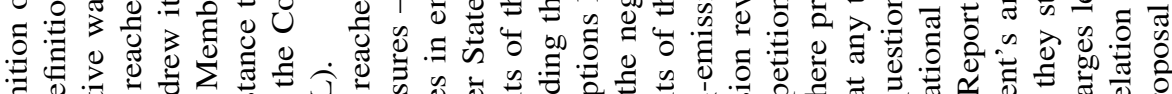

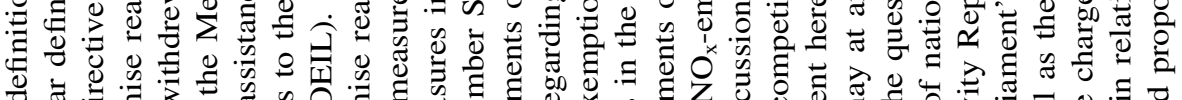

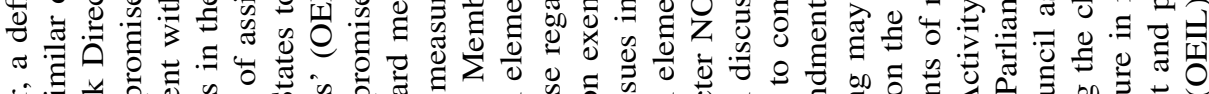

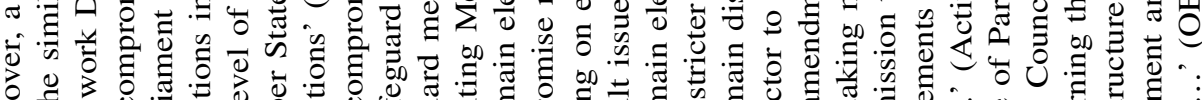

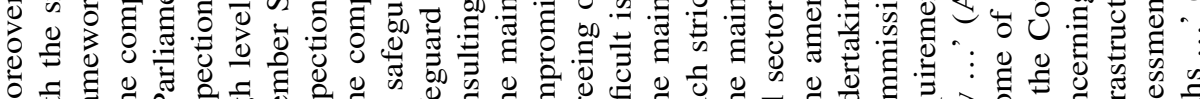

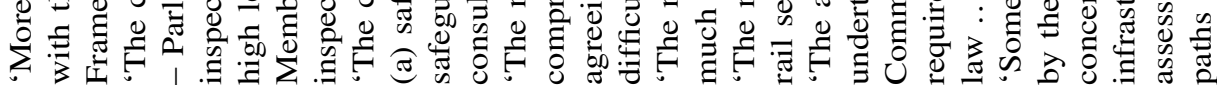
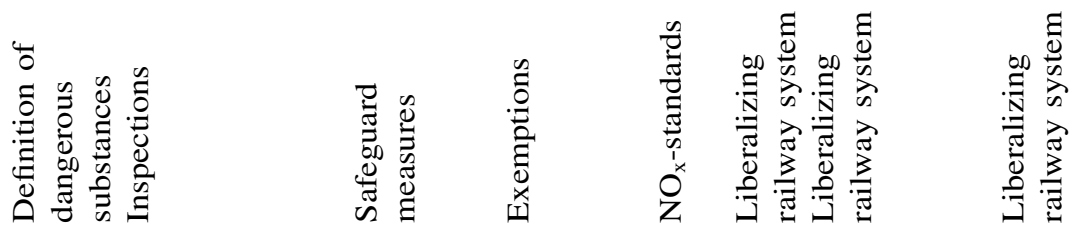

竞言

章言

童显曷

是

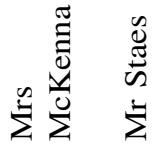

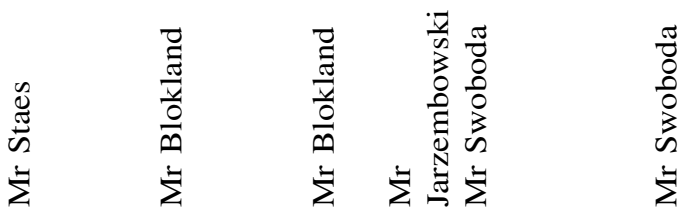

$\begin{array}{ll}\stackrel{2}{n} & \overline{0} \\ \stackrel{2}{\infty} & \infty \\ 2 & \stackrel{2}{\infty}\end{array}$

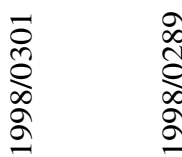

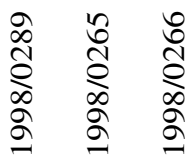

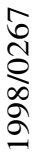

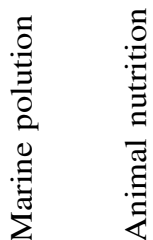

量

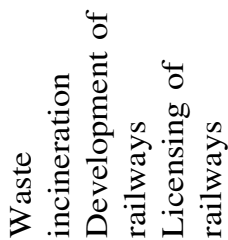

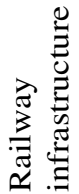




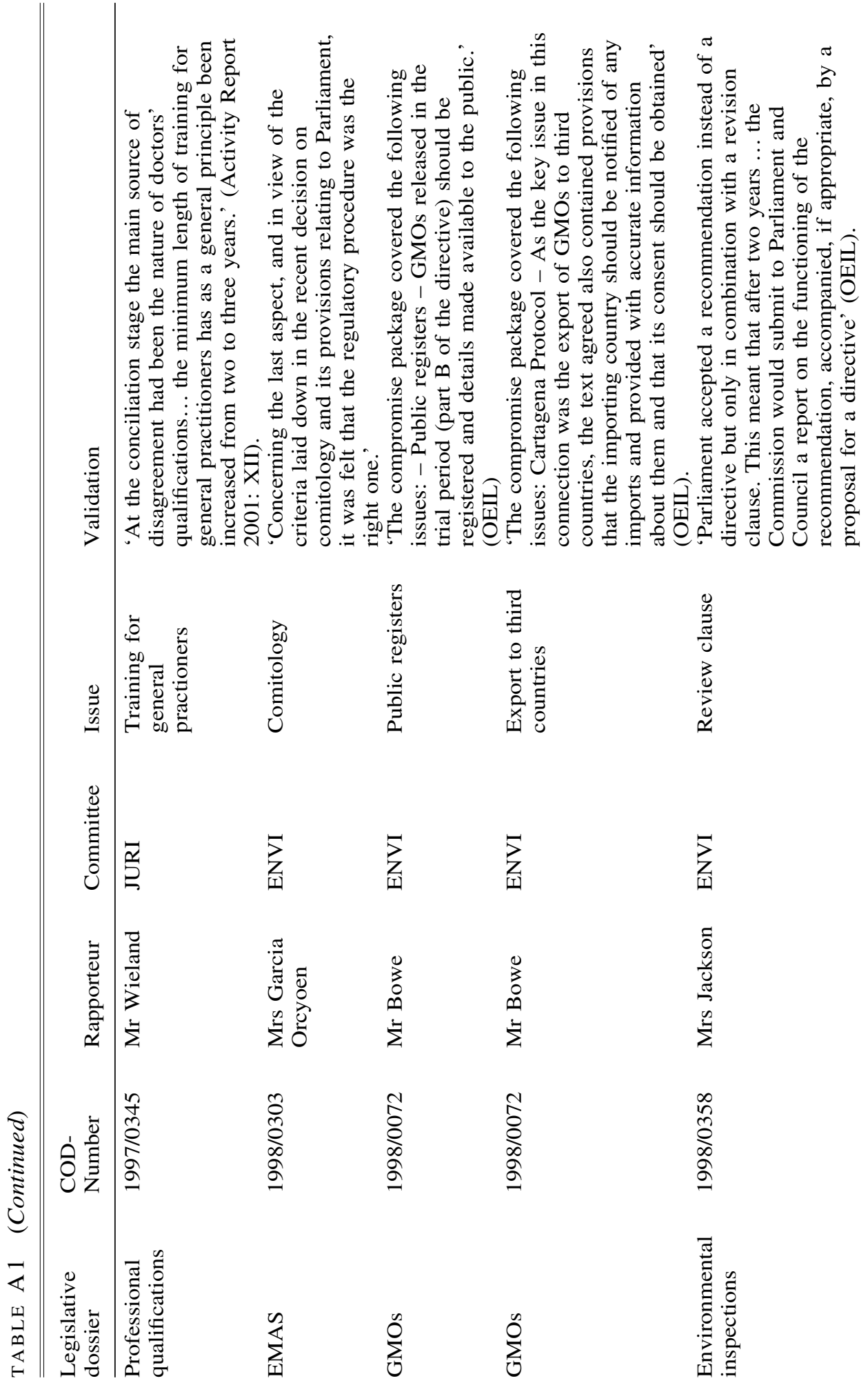




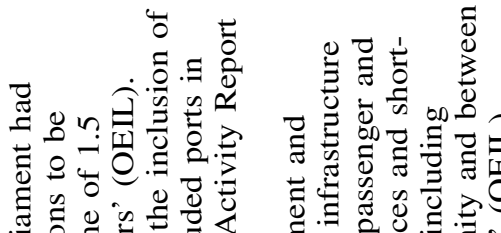

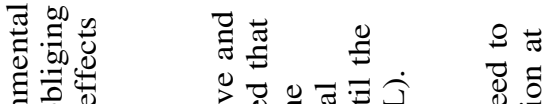

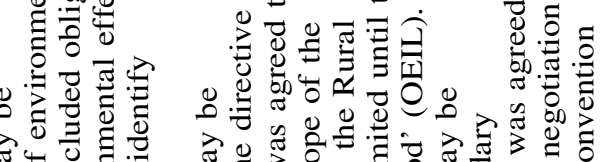

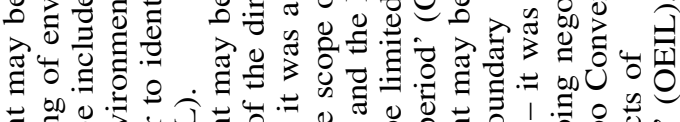

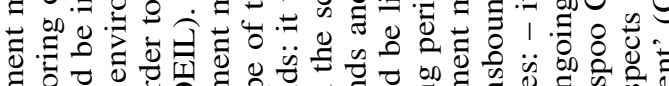

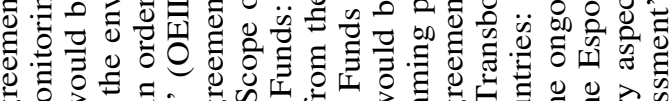

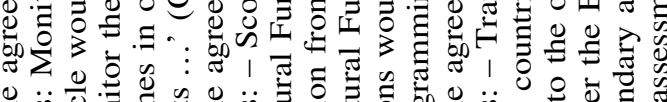

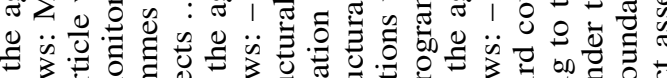

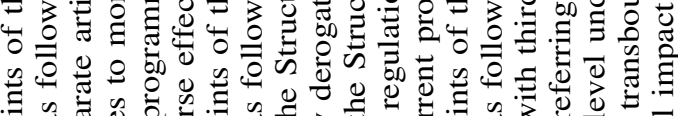

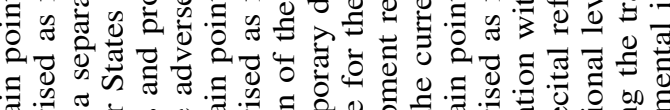

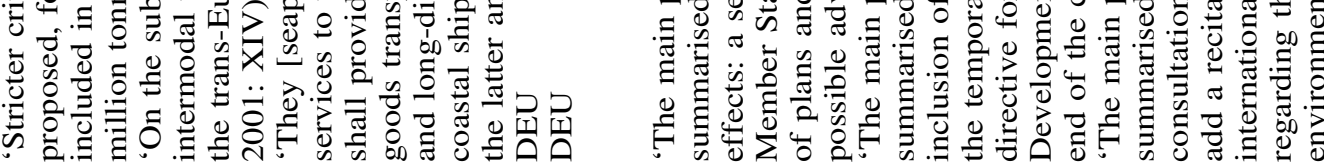

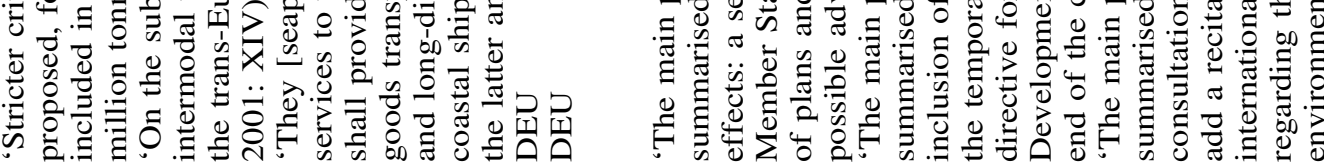

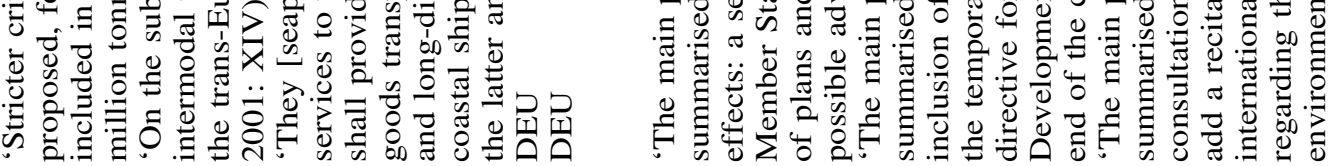

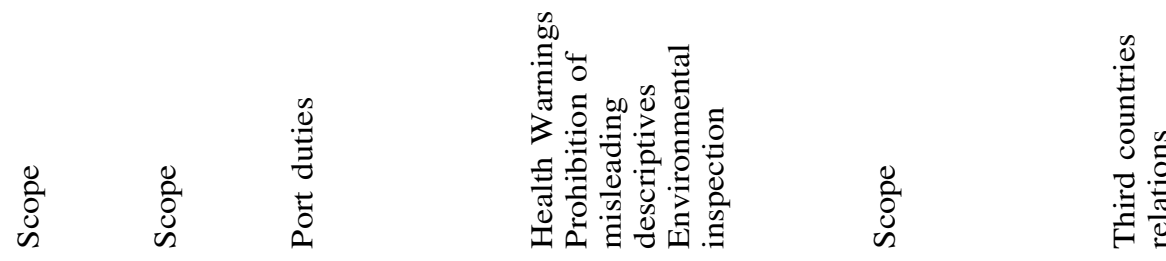

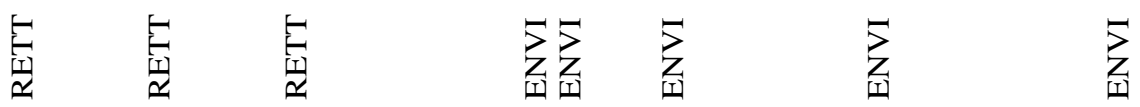

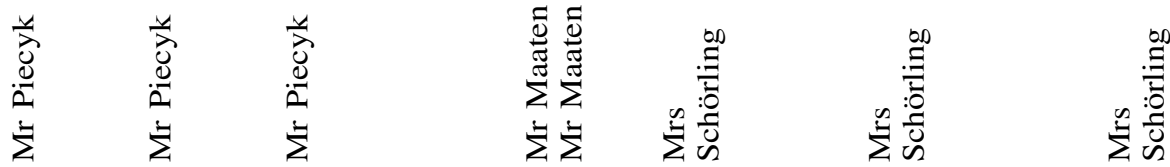

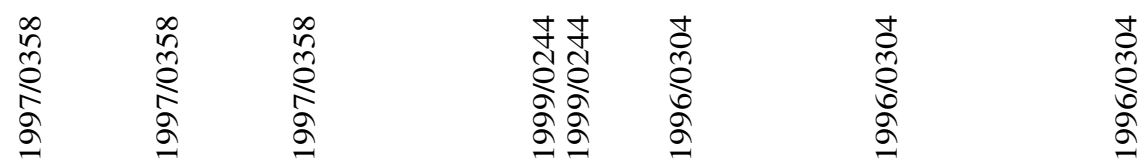

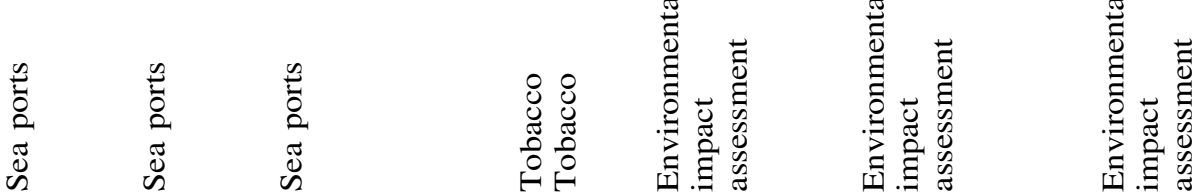




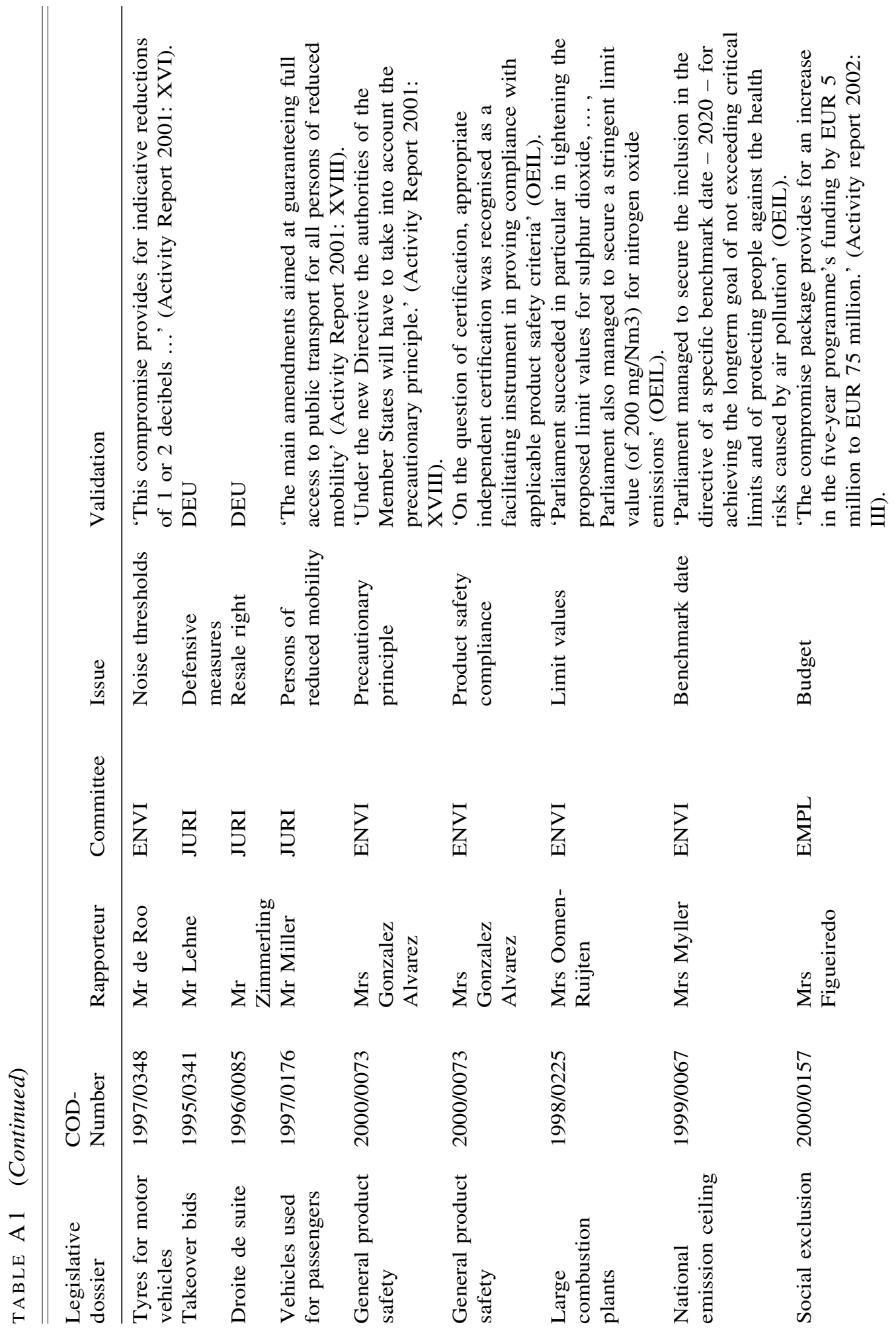




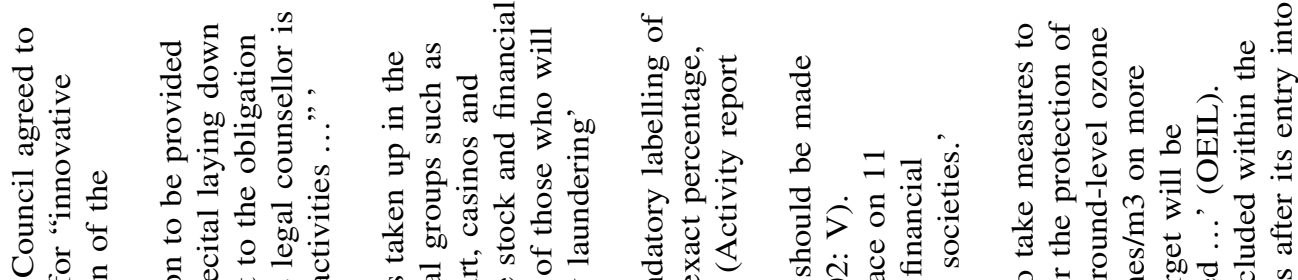

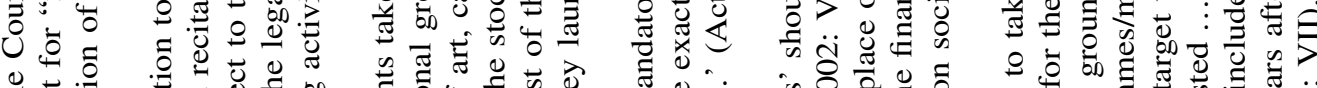

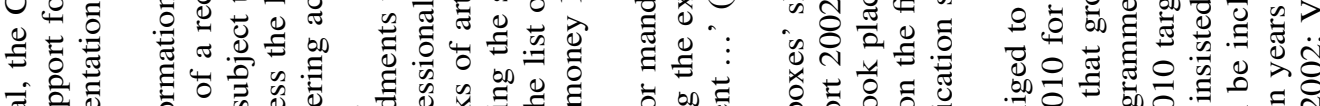

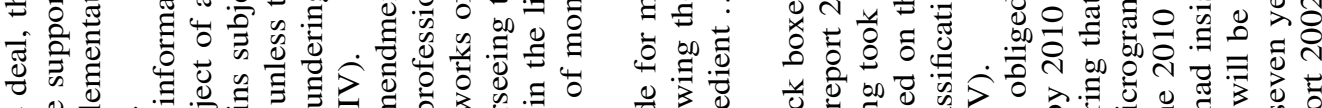
等

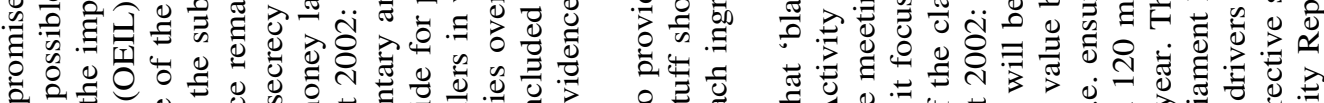

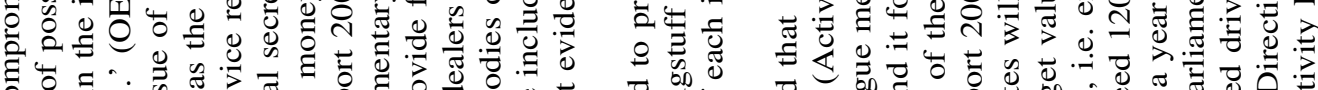

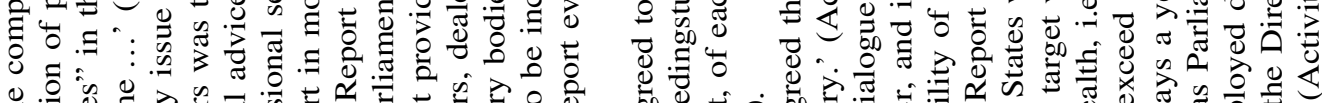

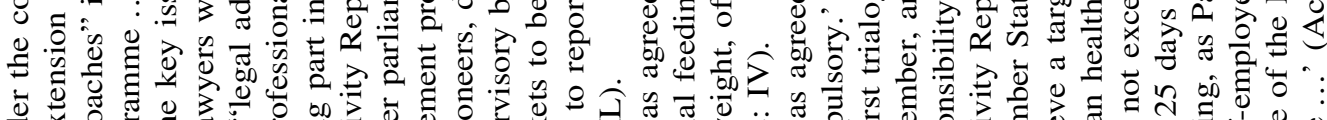

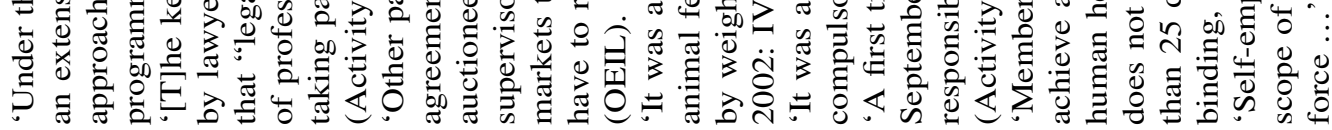

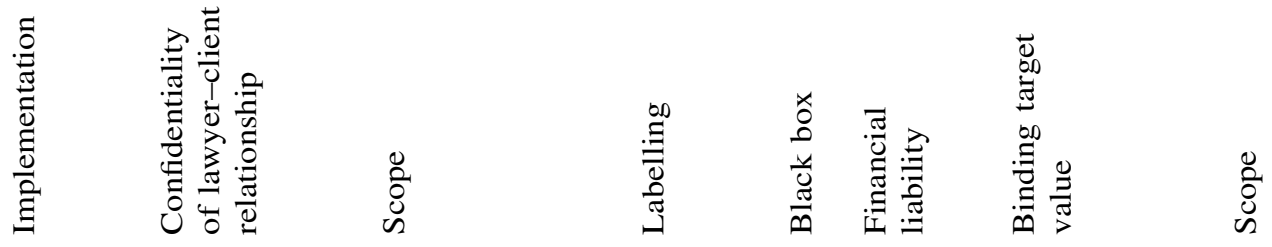

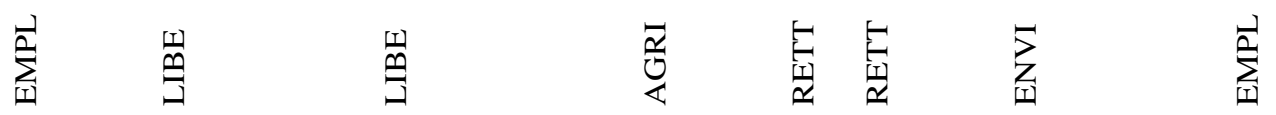

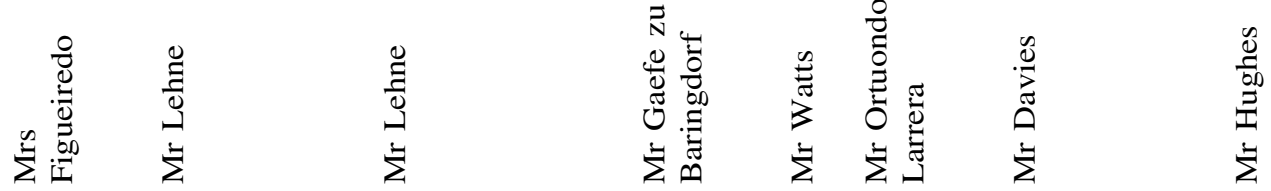

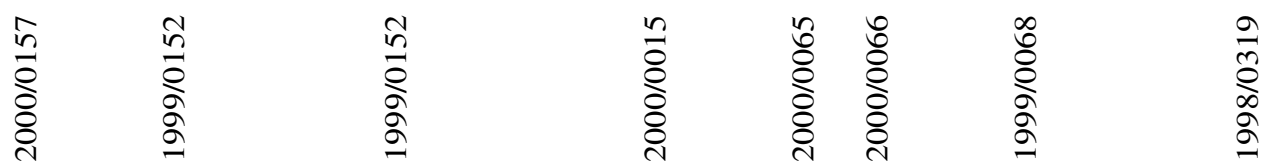

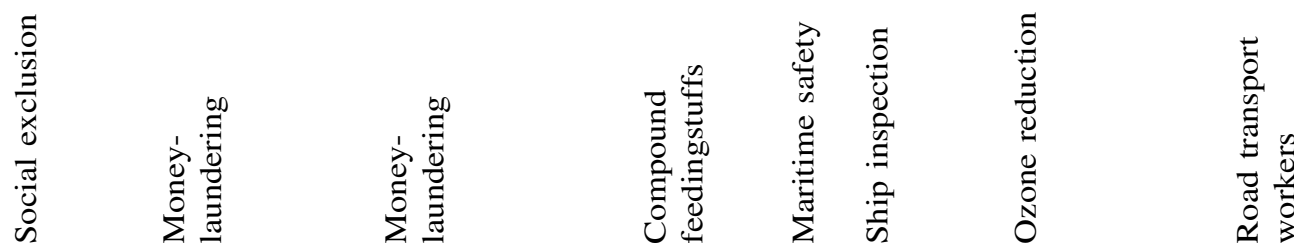




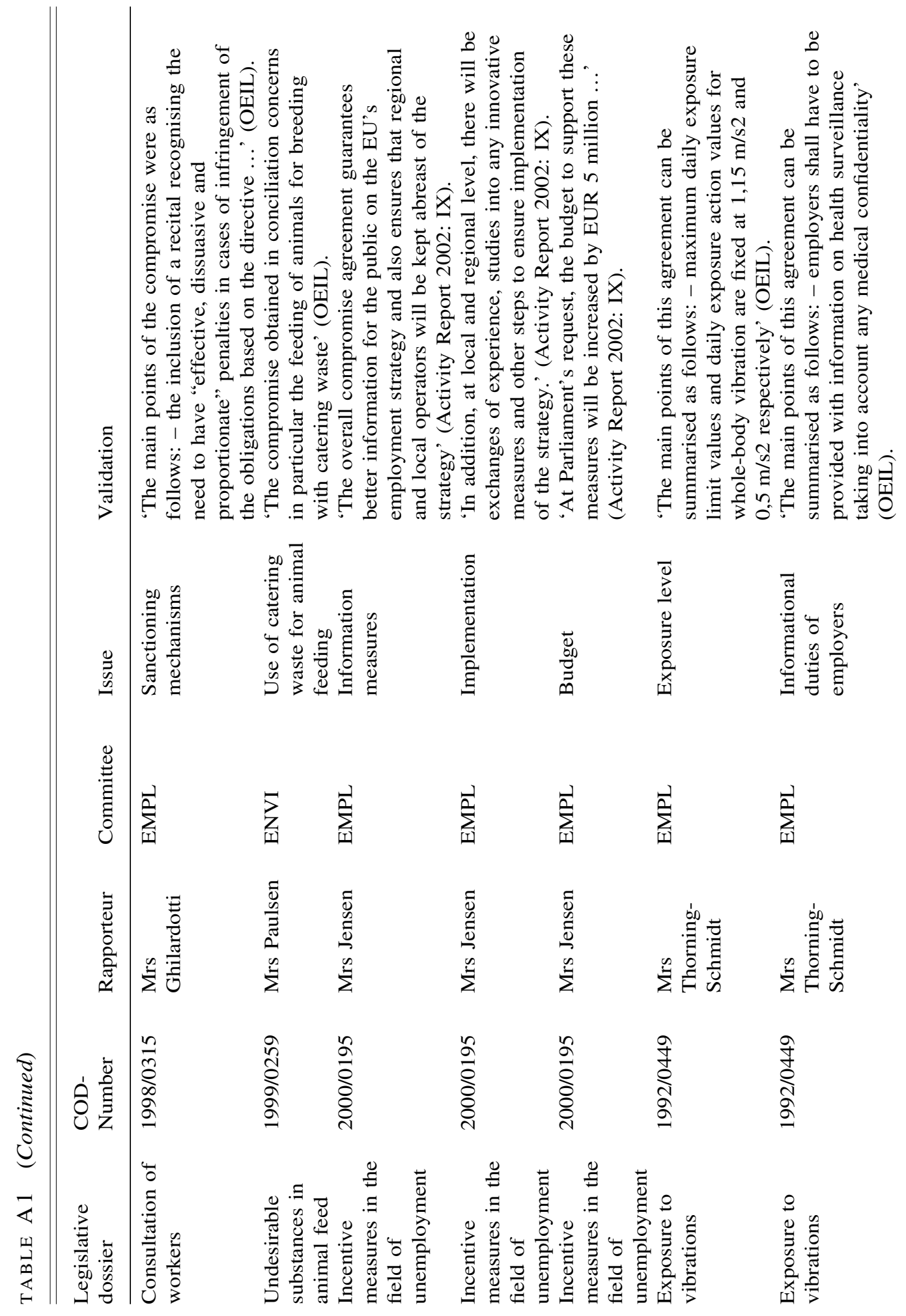




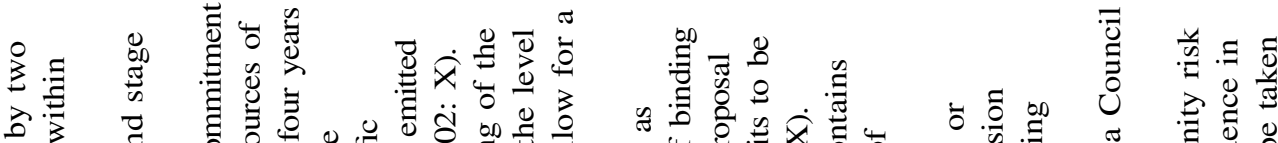

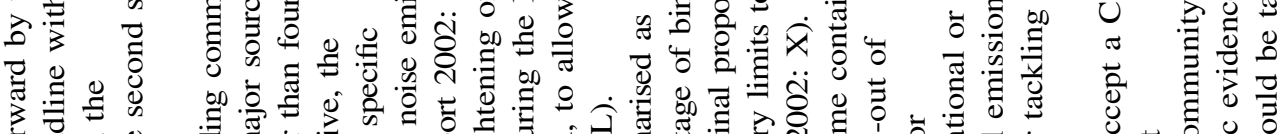

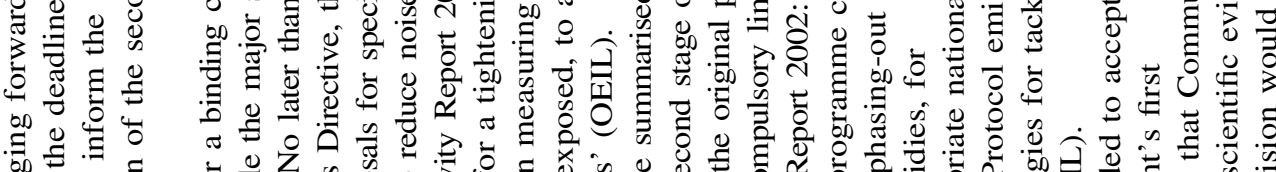

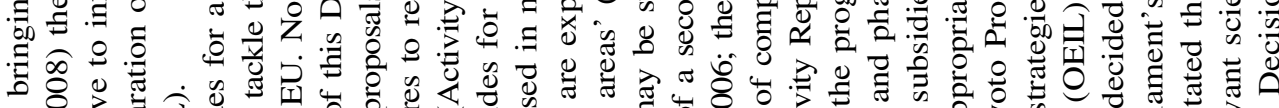

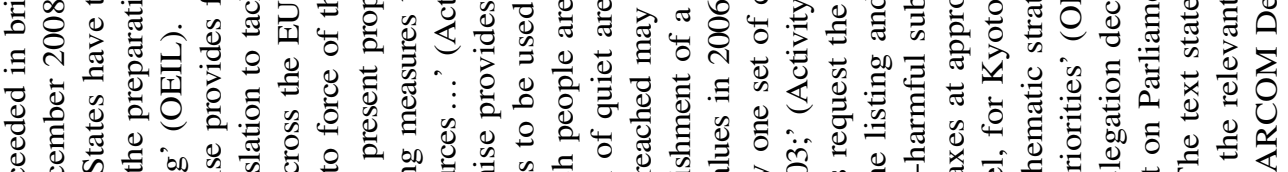

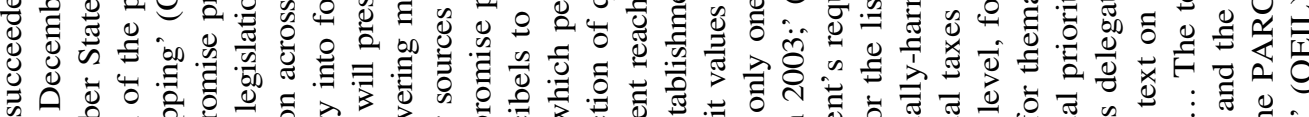

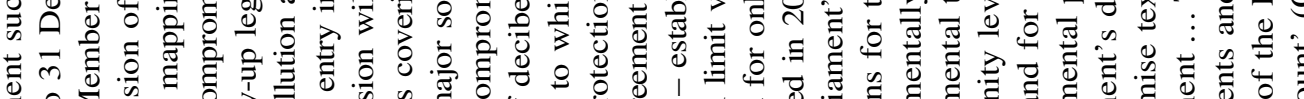

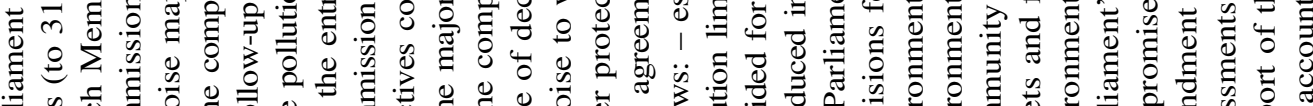

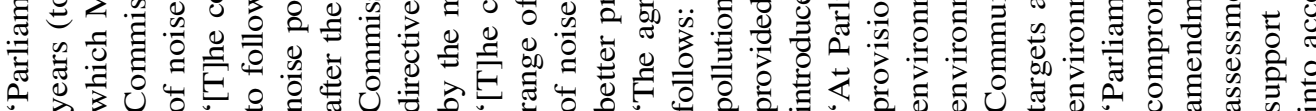
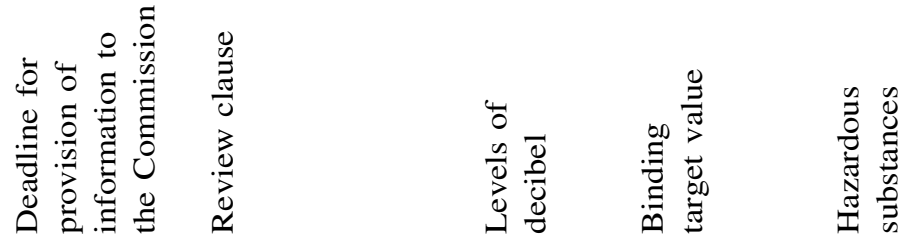

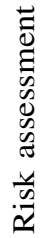

$\sum_{\text {ZI }}^{-1}$

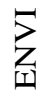<smiles>[CH]C(C)(C)C</smiles>

$\sum_{\text {I }}$

$\sum_{I}$

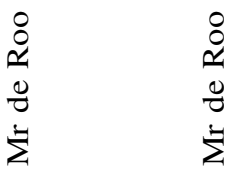

8
8
0
8



$\underset{\sum}{\stackrel{\bar{s}}{=}}$

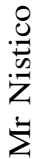

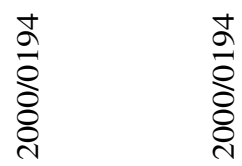

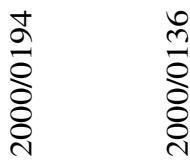

ڤे

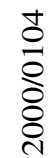

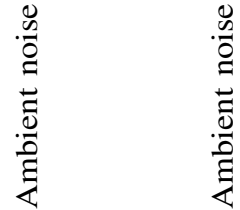

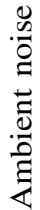

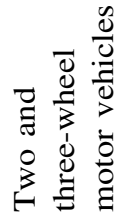

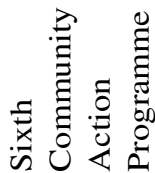

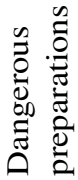




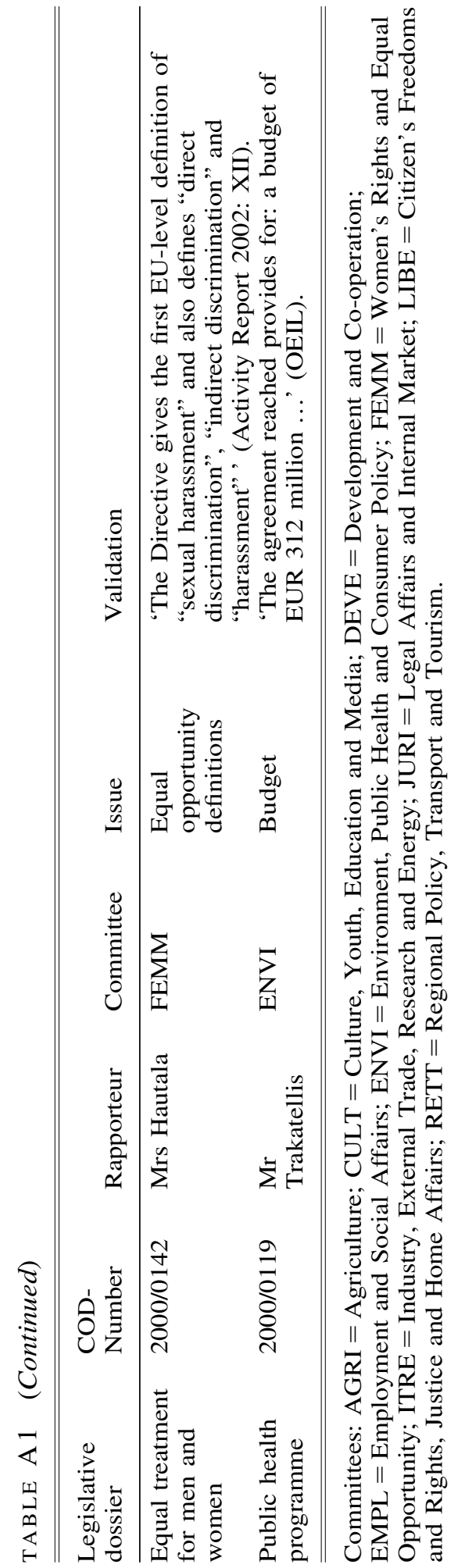

